\title{
Biogeochemical cycles and biodiversity as key drivers of ecosystem services provided by soils
}

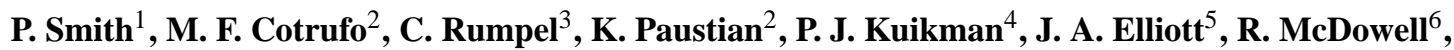 \\ R. I. Griffiths ${ }^{7}$, S. Asakawa ${ }^{8}$, M. Bustamante ${ }^{9}$, J. I. House ${ }^{10}$, J. Sobocká ${ }^{11}$, R. Harper $^{12}$, G. Pan ${ }^{13}$, \\ P. C. West ${ }^{14}$, J. S. Gerber ${ }^{14}$, J. M. Clark ${ }^{15}$, T. Adhya ${ }^{16}$, R. J. Scholes ${ }^{17}$, and M. C. Scholes ${ }^{17}$ \\ ${ }^{1}$ Institute of Biological \& Environmental Sciences, Scottish Food Security Alliance-Crops and \\ ClimateXChange, University of Aberdeen, 23 St Machar Drive, Aberdeen, AB24 3UU, UK \\ ${ }^{2}$ Department of Soil and Crop Sciences \& Natural Resource Ecology Laboratory, Colorado State University, \\ Fort Collins, CO 80523-1499, USA \\ ${ }^{3}$ CNRS, IEES (UMR UPMC, CNRS, UPEC, INRA, IRD) and Ecosys (UMR INRA, AgroParisTech), Campus \\ AgroParisTech, Bâtiment EGER, 78850 Thiverval-Grignon, France \\ ${ }^{4}$ Alterra Wageningen UR, P.O. Box 47, 6700AA Wageningen, the Netherlands \\ ${ }^{5}$ Environment Canada, National Hydrology Research Centre, Saskatoon, Saskatchewan, S7N 3H5, Canada \\ ${ }^{6}$ AgResearch, Invermay Agricultural Centre, Private Bag 50034, Mosgiel, New Zealand \\ ${ }^{7}$ Centre for Ecology \& Hydrology, Maclean Building, Benson Lane, Crowmarsh Gifford Wallingford, \\ OX10 8BB, UK \\ ${ }^{8}$ Graduate School of Bioagricultural Sciences, Nagoya University, Chikusa, Nagoya 464-8601, Japan \\ ${ }^{9}$ Departamento de Ecologia, Universidade de Brasília, I.B. C.P. 04457. Campus Universitário Darcy Ribeiro - \\ UnB. D.F. CEP: 70919-970 Brasília, Brazil \\ ${ }^{10}$ Cabot Institute, School of Geographical Sciences, University of Bristol, University Road, Bristol, \\ BS8 1SS, UK \\ ${ }^{11}$ National Agriculture and Food Centre Lužianky, Soil Science and Conservation Research Institute Bratislava, \\ Gagarinova 10, 82713 Bratislava, Slovakia \\ ${ }^{12}$ School of Environmental Science, Murdoch University, South Street, Murdoch WA, 6150, Australia \\ ${ }^{13}$ Institute of Resources, Environment and Ecosystem of Agriculture, Nanjing Agricultural University, \\ 1 Weigang, Nanjing 210095, China \\ ${ }^{14}$ Global Landscapes Initiative, Institute on the Environment (IonE), University of Minnesota, 325 Learning \& \\ Environmental Sciences, 1954 Buford Ave, St. Paul, MN 55108, USA \\ ${ }^{15}$ Soil Research Centre, Department of Geography and Environmental Science, School of Archaeology, \\ Geography and Environmental Science, University of Reading, Whiteknights, Reading, RG6 6DW, UK \\ ${ }^{16}$ School of Biotechnology, KIIT University, Bhubaneswar - 751024, Odisha, India \\ ${ }^{17}$ Global Change and Sustainability Research Institute and School of Animal, Plant and Environmental Studies, \\ University of Witwatersrand, Private Bag 3, Wits 2050, South Africa
}

Correspondence to: P. Smith (pete.smith@abdn.ac.uk)

Received: 28 April 2015 - Published in SOIL Discuss.: 1 June 2015

Revised: 2 November 2015 - Accepted: 9 November 2015 - Published: 19 November 2015

\begin{abstract}
Soils play a pivotal role in major global biogeochemical cycles (carbon, nutrient, and water), while hosting the largest diversity of organisms on land. Because of this, soils deliver fundamental ecosystem services, and management to change a soil process in support of one ecosystem service can either provide co-benefits to other services or result in trade-offs. In this critical review, we report the state-of-the-art understanding concerning the biogeochemical cycles and biodiversity in soil, and relate these to the provisioning, regulating, supporting, and cultural ecosystem services which they underpin. We then outline key knowledge gaps and research
\end{abstract}


challenges, before providing recommendations for management activities to support the continued delivery of ecosystem services from soils.

We conclude that, although soils are complex, there are still knowledge gaps, and fundamental research is still needed to better understand the relationships between different facets of soils and the array of ecosystem services they underpin, enough is known to implement best practices now. There is a tendency among soil scientists to dwell on the complexity and knowledge gaps rather than to focus on what we do know and how this knowledge can be put to use to improve the delivery of ecosystem services. A significant challenge is to find effective ways to share knowledge with soil managers and policy makers so that best management can be implemented. A key element of this knowledge exchange must be to raise awareness of the ecosystems services underpinned by soils and thus the natural capital they provide. We know enough to start moving in the right direction while we conduct research to fill in our knowledge gaps. The lasting legacy of the International Year of Soils in 2015 should be for soil scientists to work together with policy makers and land managers to put soils at the centre of environmental policy making and land management decisions.

\section{Introduction}

Soils play a critical role in delivering a variety of ecosystem services (Scholes and Scholes, 2013). Management aimed at improving a particular ecosystem service can either provide co-benefits to other services or result in trade-offs (Robinson et al., 2013). Examples of some of the synergies and trade-offs (Smith et al., 2013), the role of soils in supporting ecosystem services, and their role in underpinning natural capital (Dominati et al., 2010; Robinson et al., 2009, 2014) have recently been reviewed. The ability of soils to provide services is principally conferred by two attributes: the range of biogeochemical processes that occur in the soil and the functionality of soil biodiversity. In the following subsections we present the state-of-the-art understanding and knowledge gaps on carbon, nutrient, and water cycling in soil, as well as the role of soils as a habitat for organisms and as a genetic pool. We clarify how the biogeochemical processes provide regulating, provisioning, and supporting services, as well as the role of biodiversity (genetic diversity, functional diversity, and abundance and activity of organisms) in supporting these services. These functions collectively confer soil health, which is critical for the underpinning of cultural services, among other things. A range of soil services have been identified including soil as a source of raw materials such as sand or clay, a surface for building infrastructure, and an archive for landscape development and history of human soil use (e.g. Blum, 2002), but here we focus on those that map on to ecosystem services listed in the Millenium Ecosystem Assessment (MA) (Millennium Ecosystem Assessment, 2005).

The MA classified ecosystem services into supporting, regulating, provisioning, and cultural services, and this categorization is widely used, and though the scheme was not designed to fit all assessments (Fisher et al., 2009), it has been modified for use in national ecosystem assessments (e.g. UKNEA, 2011). More recently, the Common International Classification of Ecosystem Services (CICES; HainesYoung and Potschin, 2012) was developed to support en- vironmental accounting in the European Union and in the United Nations Statistical Division (European Commission et al., 2013, 2014). A major difference between the MA and the CICES classification systems is that CICES does not include supporting services (see below), which are treated as intermediate steps in the delivery of final goods and services (Haines-Young and Potschin, 2012). In this review, we include supporting services, since they are often referred to in the literature, while accepting the CICES observation that supporting services are not of direct benefit of people, although they are of great indirect benefit. The MA supplemented by UKNEA (2011) for supporting services, provides definitions and examples of provisioning, regulating, supporting, and cultural services as follows.

Provisioning services are "physical products obtained from ecosystems" and include food (including wildharvested seafood and game, cultivated crops, wild foods, and spices), raw materials (including timber, pulp, skins, animal and vegetable fibres, organic matter, fodder, and fertilizer), genetic resources (including genes for crop improvement and health care), freshwater, minerals, medicinal resources (including pharmaceuticals, chemical models, and test and assay organisms), energy (hydropower, biomass feedstocks including biofuels, wood, and charcoal), and ornamental resources (including fashion; handicraft; jewellery; pets; worship; decoration; and souvenirs like furs, feathers, ivory, orchids, butterflies, aquarium fish, shells, etc.).

Regulating services are "benefits obtained from the regulation of ecosystem processes" and include carbon sequestration and climate regulation, waste decomposition and detoxification, pollutant immobilization and detoxification, purification of water and air, regulation of water flow (including flood alleviation), and pest and disease control.

Supporting services are "ecosystem services that are necessary for the production of all other ecosystem services" and include soil formation, nutrient cycling, water cycling, primary production, and habitat for biodiversity. 


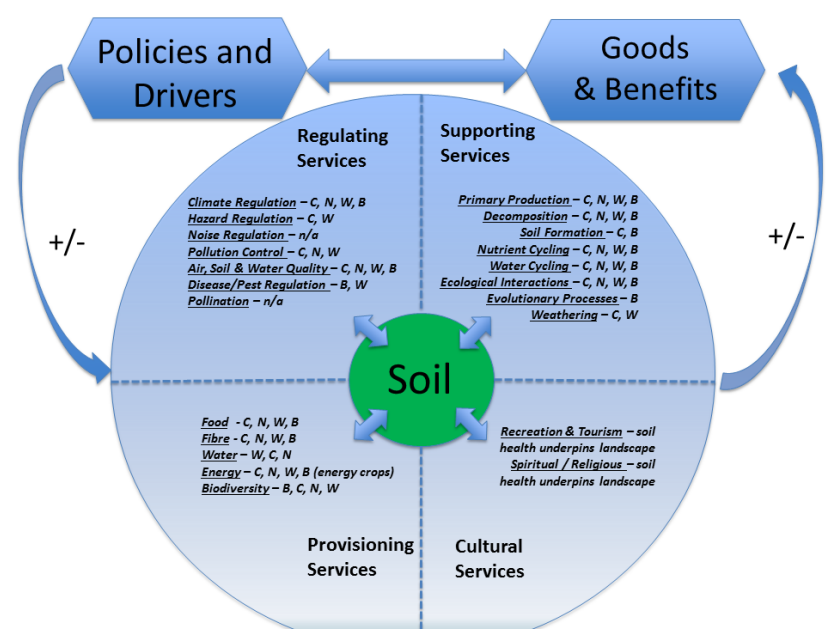

Figure 1. Schematic representation of where soil carbon, nutrient, and water cycles, and soil biota underpin ecosystem services (adapted from Smith et al., 2014). Role in underpinning each ecosystem service shown by $\mathrm{C}$, soil carbon; N, soil nutrients; W, soil water; and B, soil biota. Only soil carbon, nutrient, and water cycles, and soil biota are considered, so the figure does not represent a comprehensive overview of soil ecosystem services, which have been reviewed recently elsewhere (e.g. Robinson et al., 2013, 2014).

Cultural services are "nonmaterial benefits people obtain from ecosystems through spiritual enrichment, cognitive development, reflection, recreation, and aesthetic experiences" and include cultural (including use of nature as motif in books, film, painting, folklore, national symbols, architectural, advertising, etc.), spiritual and historical (including use of nature for religious or heritage value or sense of place), recreational experiences (including ecotourism, outdoor sports, and recreation), and science and education (including use of natural systems for school excursions and scientific discovery). Examples of cultural services underpinned by soils are the terra preta soils of the Amazon Basin, representing the historical cultural heritage of the region before European settlers; Histosols, which are a vital component of peatland landscapes, underpinning the landscape/amenity value of these valued wild areas; and soils used as building material for traditional houses providing cultural heritage values, such as the mud brick houses in Bam in Iran and Shibam in Yemen. Since this paper focuses on biogeochemical cycling and soil biota, cultural services are not discussed further in detail in this review.

Figure 1 summarizes the ecosystem services underpinned by soils. In the following sections, we examine the state-ofthe-art understanding of carbon, nutrient, and water cycles and biodiversity in soils, and show how these underpin the provisioning, regulating, supporting, and cultural ecosystem services described above. We then discuss the knowledge gaps across all of these areas, recommend key foci for future research, and present recommendations for practices and policies to support the continued delivery of these ecosystem services from soils.

\section{Soils and the carbon cycle}

Soil C stocks: Carbon (C) storage is an important ecosystem function of soils that has gained increasing attention in recent years. Changes in soil $\mathrm{C}$ impacts on, and feedbacks to, the Earth's climate system through emissions of $\mathrm{CO}_{2}$ and $\mathrm{CH}_{4}$ as well as storage of carbon removed from the atmosphere during photosynthesis (climate regulation; Table 1). Soil organic matter itself also confers multiple benefits for human society, e.g. enhancing water purification and water holding capacity, protecting against erosion risk, and enhancing food and fibre provision through improved soil fertility (Table 1; Pan et al., 2013, 2014).

Soil is an important $\mathrm{C}$ reservoir that contains more $\mathrm{C}$ (at least $1500-2400 \mathrm{Pg} \mathrm{C}$ ) than the atmosphere (590 Pg C) and terrestrial vegetation (350-550 Pg C) combined (Schlesinger and Bernhardt, 2013; Ciais et al., 2013), and an increase in soil $\mathrm{C}$ storage can reduce atmospheric $\mathrm{CO}_{2}$ concentrations (Table 1; Whitmore et al., 2014). All three reservoirs of $\mathrm{C}$ are in constant exchange but with various turnover times, with soil as the largest active terrestrial reservoir in the global $\mathrm{C}$ cycle (Lal, 2008). Carbon storage in soils occur in both organic and inorganic form. Organic C stocks in the world's soils have been estimated to comprise $1500 \mathrm{Pg}$ of $\mathrm{C}$ to $1 \mathrm{~m}$ depth and $2500 \mathrm{Pg}$ to $2 \mathrm{~m}$ (Batjes, 1996). Recent studies have shown that the soil $\mathrm{C}$ pool to $1 \mathrm{~m}$ depth may be even greater and could account for as much as $2000 \mathrm{Pg}$. These higher values are mainly based on increased estimates of the $\mathrm{C}$ stored in boreal soils under permafrost conditions (Tarnocai et al., 2009), in which decomposition is inhibited by low temperature, lack of oxygen, and low $\mathrm{pH}$ in waterlogged soils, e.g. peats (Smith et al., 2010). Although the highest $C$ concentrations are found in the top $30 \mathrm{~cm}$ of soil, the major proportion of total $\mathrm{C}$ stock is present below $30 \mathrm{~cm}$ depth (Batjes, 1996). In the northern circumpolar permafrost region, at least $61 \%$ of the total soil C is stored below $30 \mathrm{~cm}$ depth (Tarnocai et al., 2009). Peatlands are particularly important components of the global soil carbon store, covering only $3 \%$ of the land area but containing around $500 \mathrm{Pg} \mathrm{C}$ in organic-rich deposits ranging from 0.5 to $8 \mathrm{~m}$ deep (Gorham, 1991; Yu, 2012), with storage in deeper layers as yet unquantified.

In arid and semi-arid soils, significant inorganic $\mathrm{C}$ can be present as carbonate minerals (typically $\mathrm{Ca} / \mathrm{MgCO}_{3}$, called "calcrete" or "caliche" in various parts of the world), formed from the reaction of bicarbonate (derived from $\mathrm{CO}_{2}$ in the soil) with free base cations, which can then be precipitated in subsoil layers (Nordt et al., 2000). Soils derived from carbonate-containing parent material (e.g. limestone) can also have significant amounts of inorganic $\mathrm{C}$. The inorganic C pool globally is large, estimated to be $\sim 750 \mathrm{Pg}$ $\mathrm{C}$ to a depth of $1 \mathrm{~m}$ (Batjes, 1996). However, in most cases, 
Table 1. Management actions affecting the soil carbon cycle and their impact on ecosystem services.

\begin{tabular}{|c|c|c|c|c|}
\hline $\begin{array}{l}\text { Management action or } \\
\text { other driver of change }\end{array}$ & $\begin{array}{l}\text { Provisioning service } \\
\text { impact }\end{array}$ & $\begin{array}{l}\text { Regulating service } \\
\text { impact }\end{array}$ & $\begin{array}{l}\text { Supporting service } \\
\text { impact }\end{array}$ & $\begin{array}{l}\text { Cultural service im- } \\
\text { pact }\end{array}$ \\
\hline $\begin{array}{l}\text { Land use change } \\
\text { (conversion of for- } \\
\text { est/grassland/wetland } \\
\text { to cropland) }\end{array}$ & $\begin{array}{l}\text { Increased production } \\
\text { of food, fibre, and en- } \\
\text { ergy crops; reduced } \\
\text { availability of natural } \\
\text { raw materials; poten- } \\
\text { tial change in hydrol- } \\
\text { ogy/water availability }\end{array}$ & $\begin{array}{l}\text { Decreased soil C } \\
\text { sequestration and } \\
\text { storage - increased } \\
\text { GHG flux; increased } \\
\text { erosion and sediment } \\
\text { yield - reduced regu- } \\
\text { lations of water flow } \\
\text { and quality }\end{array}$ & $\begin{array}{l}\text { Primary production } \\
\text { may be changed; } \\
\text { nutrient recycling } \\
\text { reduced if no inputs, } \\
\text { increased if there are } \\
\text { inputs }\end{array}$ & $\begin{array}{l}\text { Lower recreation } \\
\text { value; may have im- } \\
\text { pact on cultural value } \\
\text { in recreating diverse } \\
\text { landscapes }\end{array}$ \\
\hline $\begin{array}{l}\text { Land use change (es- } \\
\text { tablishment of forest } \\
\text { or grassland on agri- } \\
\text { cultural land) }\end{array}$ & $\begin{array}{l}\text { Raw material pro- } \\
\text { vision may be } \\
\text { increased; agricultural } \\
\text { production likely } \\
\text { decreased (but not } \\
\text { always, e.g. agro- } \\
\text { forestry) }\end{array}$ & $\begin{array}{l}\text { Increased C seques- } \\
\text { tration; increased reg- } \\
\text { ulation of water flow } \\
\text { and quality }\end{array}$ & $\begin{array}{lr}\text { Primary } & \text { production } \\
\text { may be } & \text { changed; } \\
\text { increased } & \text { water } \\
\text { recycling } & \end{array}$ & $\begin{array}{l}\text { Increased recreation } \\
\text { value; may have im- } \\
\text { pact on cultural value } \\
\text { in recreating diverse } \\
\text { landscapes }\end{array}$ \\
\hline $\begin{array}{lr}\text { Intensified } & \text { nutrient } \\
\text { management } & \text { through } \\
\text { fertilization } & \text { and } \\
\text { liming } & \end{array}$ & $\begin{array}{l}\text { Increased production } \\
\text { of food and other raw } \\
\text { materials }\end{array}$ & $\begin{array}{l}\text { Effect on net soil C se- } \\
\text { questration uncertain; } \\
\text { increased GHG flux } \\
\text { from fertilizer produc- } \\
\text { tion and use; water } \\
\text { and air pollution }\end{array}$ & $\begin{array}{l}\text { Increased primary } \\
\text { production; increased } \\
\text { nutrient recycling }\end{array}$ & \\
\hline $\begin{array}{l}\text { Soil amelioration us- } \\
\text { ing organic amend- } \\
\text { ments such as com- } \\
\text { post and biochar }\end{array}$ & $\begin{array}{l}\text { Increased food pro- } \\
\text { duction; more raw } \\
\text { materials; more water } \\
\text { available for plant } \\
\text { growth }\end{array}$ & $\begin{array}{l}\text { Increased C seques- } \\
\text { tration; increased wa- } \\
\text { ter purification value }\end{array}$ & $\begin{array}{l}\text { Increased primary } \\
\text { production; increased } \\
\text { nutrient cycling; } \\
\text { improved water infil- } \\
\text { tration and retention }\end{array}$ & \\
\hline $\begin{array}{l}\text { Diversification of } \\
\text { crop production } \\
\text { systems (i.e. more } \\
\text { perennials, reduced } \\
\text { bare fallow) }\end{array}$ & $\begin{array}{l}\text { Potential impact on } \\
\text { agricultural produc- } \\
\text { tion }( \pm) ; \text { more diverse } \\
\text { products }\end{array}$ & $\begin{array}{l}\text { Increased C seques- } \\
\text { tration; increased pu- } \\
\text { rification value }\end{array}$ & $\begin{array}{l}\text { Changed primary pro- } \\
\text { duction; increased nu- } \\
\text { trient retention; im- } \\
\text { proved water infiltra- } \\
\text { tion and retention }\end{array}$ & $\begin{array}{l}\text { Improved cultural } \\
\text { value from more } \\
\text { diverse landscapes }\end{array}$ \\
\hline $\begin{array}{l}\text { Replacement of hay } \\
\text { forage production } \\
\text { with pasture use on } \\
\text { grasslands }\end{array}$ & No impact & $\begin{array}{l}\text { Effect on } \mathrm{C} \text { sequestra- } \\
\text { tion uncertain }\end{array}$ & & $\begin{array}{l}\text { Increased recreation } \\
\text { value; may have im- } \\
\text { pact on cultural value } \\
\text { in recreating diverse } \\
\text { landscapes }\end{array}$ \\
\hline $\begin{array}{l}\text { Improved grazing } \\
\text { management }\end{array}$ & $\begin{array}{l}\text { Increased food pro- } \\
\text { duction; reduced } \\
\text { runoff and improved } \\
\text { water use }\end{array}$ & $\begin{array}{l}\text { Increased C seques- } \\
\text { tration; increased pu- } \\
\text { rification value; water } \\
\text { flow regulation }\end{array}$ & $\begin{array}{l}\text { Increased primary } \\
\text { production; improved } \\
\text { water infiltration and } \\
\text { retention }\end{array}$ & \\
\hline
\end{tabular}

changes in inorganic $\mathrm{C}$ stocks are slow, are not amenable to traditional soil management practices, and do not play a significant role in terms of most ecosystem services (though a major exception is the geoengineering proposal to add finely ground silicate minerals to soils, which will then weather to carbonates, taking up $\mathrm{CO}_{2}$ in the process; Köhler et al., 2010). Thus, further discussion of soil $\mathrm{C}$ in this review will focus on soil organic $\mathrm{C}$.
The net balance of soil $\mathrm{C}$ depends on the inputs of $\mathrm{C}$ to soils relative to $\mathrm{C}$ losses. Losses can occur via mineralization (i.e. decomposition), leaching of dissolved C, and carbonate weathering (Smith, 2012; Schlesinger and Bernhardt, 2013). Thus, the soil organic $C$ stock may either increase or decrease in response to changes in climate and land use practices (Smith et al., 2015). Furthermore, rates of SOC stock change in different parts of the profile can vary for different 
soils and types of perturbation, because some portion of the $\mathrm{C}$ stored in soil, mainly in topsoil, turns over rapidly, while other soil $\mathrm{C}$ fractions can have a long residence time (von Lützow et al., 2008; Rumpel and Kögel-Knabner, 2011). The accumulation of stabilized $\mathrm{C}$ with long residence times in deep soil horizons may be due to continuous transport, temporary immobilization and microbial processing of dissolved organic matter within the soil profile (Kalbitz and Kaiser, 2012), and/or efficient stabilization of root-derived organic matter within the soil matrix (Rasse et al., 2005). The process of soil formation - i.e. the development of depth, horizons, and specific properties - is itself a supporting service (Table 1).

High SOC content also improves other chemical and physical soil properties, such as nutrient storage (supporting service), water holding capacity (supporting and regulating service), aggregation, and sorption of organic or inorganic pollutants (regulating service). Carbon sequestration in soils may therefore be a cost-effective and environmentally friendly way to not only store $\mathrm{C}$ for climate regulation but also enhance other ecosystem services derived from soil, such as agricultural production, clean water supply, and biodiversity (Table 1; Pan et al., 2013) by improving soil organic matter (SOM) content and thereby soil quality (Lal, 2004). Moreover, processes which improve SOM may themselves provide services, e.g. use of cover crops, which can provide provisioning or water regulation services while improving soil C (Table 1). SOM or soil carbon are widely used proxy variables for soil health (e.g. Kibblewhite et al., 2008).

$C$ cycling: Carbon enters the soil as aboveground or belowground plant litter and exudates. C input is not homogenous within the soil profile. Whereas topsoil receives higher amounts of aboveground litter, subsoil $\mathrm{C}$ originates from root $\mathrm{C}$ as well as dissolved $\mathrm{C}$, transported down the soil profile. Root $\mathrm{C}$ has a greater likelihood of being preserved in soil compared to shoot $\mathrm{C}$, and was therefore hypothesized to account for most of the SOC (Rasse et al., 2005). The majority of plant litter compounds pass through and are modified by the soil biota. Thus, SOM is composed of plant litter compounds as well as microbial and, to a smaller extent, faunal decomposition products (Paul, 2014). It is a complex biogeochemical mixture comprising molecules derived from organic material in all stages of decomposition. Some organic matter compounds, including microbial decomposition products, may be stabilized for centuries to millennia by binding to soil minerals or by physical occlusion into micro-aggregates (von Lützow et al., 2008), for example with iron oxyhydrates (Zhou et al., 2009), or through protection by occlusion within soil aggregates (Dungait et al., 2012). The inherent chemical recalcitrance of some plant litter compounds (e.g. lignin) has a minor influence on their longevity in soil (Thévenot et al., 2010), whereas the location of SOM within the soil matrix has a much stronger control on its turnover (Chabbi et al., 2009; Dungait et al., 2012). Mineralassociated SOM is predominantly composed of microbial products (Miltner et al., 2012). Therefore, microbial use efficiency of plant inputs largely determines SOM stabilization through interaction with the mineral phase (Cotrufo et al., 2013), in addition to the environmental controls discussed elsewhere in this section. In peatlands, organic matter is stabilized by high water tables that slow down biological activity and decomposition. SOM is mineralized to carbon dioxide $\left(\mathrm{CO}_{2}\right)$ in aerobic environments, or reduced to methane $\left(\mathrm{CH}_{4}\right)$ in anaerobic environments. Soil $\mathrm{CO}_{2}$ efflux, resulting from SOM mineralization, and from rhizosphere respiration and inorganic $\mathrm{C}$ weathering, is the largest terrestrial flux of $\mathrm{CO}_{2}$ to the atmosphere $(\sim 60 \mathrm{Pg} \mathrm{C}$; the sink of carbon on the other hand contributes to the climate regulation service; Smith, 2004). This flux is an order of magnitude larger than anthropogenic $\mathrm{CO}_{2}$ emissions due to fossil fuel burning and land use change (1.1 $\mathrm{Pg} \mathrm{Cyr}^{-1}$; Ciais et al., 2013). Under anaerobic conditions, $\mathrm{CH}_{4}$ is formed by methanogenic microorganisms. A proportion of this $\mathrm{CH}_{4}$ is oxidized to $\mathrm{CO}_{2}$ by methanotrophic microorganisms, but a proportion can be emitted from the soil surface (Reay et al., 2010). Since $\mathrm{CH}_{4}$ is many times more potent as a greenhouse gas than $\mathrm{CO}_{2}$ on a per-molecule or per-mass basis (Ciais et al., 2013), soil $\mathrm{CH}_{4}$ emissions and their mitigation play an important role in climate regulation (Table 1).

Fire may affect many ecosystem services, including $\mathrm{C}$ sequestration. For fires in natural ecosystems, a decrease in soil C storage is often observed initially, but through positive effects on plant growth, as well as input of very stable pyrogenic $\mathrm{C}, \mathrm{C}$ storage may increase at longer timescales (Knicker, 2007). An additional long-term C pool in many soils is pyrogenic carbon (PyC), formed from partially combusted (i.e. pyrolysed) biomass during wildfires or other combustion processes (Schmidt and Noack, 2000). Globally, soils are estimated to contain between 54 and $109 \mathrm{Pg} \mathrm{PyC}$ (Bird et al., 2015). Some of this PyC has a highly condensed aromatic structure that retards microbial decay, and can thus persist in soils for relatively long periods (Singh et al., 2012). Soil amended with industrially produced $\mathrm{PyC}$ (biochar) as a climate mitigation technique often shows no increase in soil respiration despite the additional carbon, the reduced ecosystem carbon turnover results in increased soil carbon storage (Stewart et al., 2013). PyC additions to soil affect regulating ecosystem services, such as $\mathrm{C}$ sequestration, nutrient cycling, and adsorption of contaminants. However, PyC properties, and as result their effect on ecosystem services, may be strongly dependent on fire conditions.

Factors influencing soil C storage: Fundamentally, the amount of $\mathrm{C}$ stored in a given soil is determined by the balance of $\mathrm{C}$ entering the soil, mainly via plant production but also through manures or amendments such as organic sludge or biochar, and $\mathrm{C}$ leaving the soil through mineralization (as $\mathrm{CO}_{2}$ ), driven by microbial processes, and to a lesser extent leaching out of the soil of dissolved carbon and carbonate weathering. Locally, C can be lost or gained through soil 
erosion or deposition, leading to a redistribution of soil $\mathrm{C}$, at landscape and regional scales (van Oost et al., 2007).

Consequently, the main controls on soil $\mathrm{C}$ storage are the amount and type of organic matter inputs, the efficiency by which this is used by microbes, and the capacity of the soil to retain it by physical or chemical stabilization (Cotrufo et al., 2013). In most natural and agricultural ecosystems, plant productivity and subsequent death and senescence of biomass provide the input of organic $\mathrm{C}$ to the soil system (Table 1). Thus, higher levels of plant residue inputs will tend to support higher soil organic carbon stocks, and vice versa (Paustian et al., 1997), though this does not continue indefinitely (Zvomuya et al., 2008). Plants also affect soil C cycling by their specific mycorrhizal associations (Brzostek et al., 2015). Shifts in specific mycorrhizal associations affect SOM storage by contributing to both SOM formation and decomposition. Ectomychorrizhal turnover is a dominant process of SOM formation (Godbold et al., 2006), possibly due to the more recalcitrant nature of the chitin in fungal tissues, compared to the cellulose and lignin in plant residues. In arbuscular mycorrhizal fungi, it has been suggested that glomalin, a highly resistant glycoprotein, has an active role in aggregate formation and SOM stocks (Rillig, 2004). Symbiotic mycorrhizal fungi can also directly impact the turnover of organic matter by the production of exo-enzymes (Averill et al., 2014; Finzi et al., 2015).

In many regions of the world, SOM accumulates because of inhibition of microbial SOM decomposition, due to cold, dry, or anoxic conditions (Trumbore, 2009). In general, when water is not limiting, higher soil temperatures increase the rate of microbial decomposition of organic matter. Thus soil temperature is a major control of SOM storage in soil C cycle models (Peltoniemi et al., 2007). The temperature sensitivity of SOM decomposition is not, however, as straightforward as represented in most models but varies between the many different forms of chemical and physical protection of organic matter in soil (Conant et al., 2011; Zheng et al., 2012). Water influences soil C storage through several processes. Moist, but well-aerated, soils are optimal for microbial activity and decomposition rates decrease as soils become drier. However, flooded (saturated) soils have lower rates of organic matter decay due to restricted aeration and thus often have very high amounts of soil C (e.g. peat soils). High precipitation may also lead to $\mathrm{C}$ transport down the soil profile as dissolved and/or particulate organic matter, as well as lateral transport through soil erosion and deposition. During dry periods, SOM decomposition is decreased, but after rewetting there may be an accelerated pulse of $\mathrm{CO}_{2}$ emission in aerobic soils (Borken and Matzner, 2008), whereas drought and lowering water tables may increase decomposition in naturally anaerobic peats (Freeman et al., 2001; Clark et al., 2012). However, the effect of drought is not only direct via soil microbial activity. There are feedback loops concerning drought and $\mathrm{C}$ storage via plant activities, such as litter input and rhizodeposition. Drought was found to affect plant litter composition (Sanaullah et al., 2014), plant C flow and root exudation (Sanaullah et al., 2012), as well as the resulting enzyme activities in the rhizosphere (Sanaullah et al., 2011).

$\mathrm{C}$ cycling in soils is strongly linked to the cycling of $\mathrm{N}$ and $\mathrm{P}$. Since the $\mathrm{C}: \mathrm{N}: \mathrm{P}$ stoichiometry in SOM is generally lower than in plant material - i.e. there is more $\mathrm{N}$ and $\mathrm{P}$ per unit $\mathrm{C}-\mathrm{C}$ generally accumulates in aerobic soil where nutrients are not limiting (Alberti et al., 2014). Nevertheless, an increase in organic $\mathrm{C}$ is often accompanied by increased $\mathrm{N}$ resource use efficiency in croplands (Pan et al., 2009), especially when SOC is increased with biochar (Huang et al., 2013). In nutrient-limited peatlands, inputs of nitrogen and/or phosphorus within the tolerance levels of sensitive plant species have increased rates of carbon accumulation (Aerts et al., 1992; Turunen et al., 2004; Olid et al., 2014). The relationship between nutrients and $\mathrm{C}$ cycling is not straightforward, since nutrients are also needed by soil microbes to degrade SOM. Thus, nutrient addition can either decrease or increase $\mathrm{C}$ storage, depending on the initial SOM stoichiometry, the ability of the soil minerals to stabilize microbial products of decomposition, and the simultaneous effects on plant productivity and organic matter inputs to soils.

The amount and type of clay particles (and to a lesser extent silt particles) are the major factors controlling the quantity and composition of soil C (Sollins et al., 1996; von Lützow et al., 2006). Clays are mainly sheet-like crystals of silicon and aluminium, known as phyllosilicates, often located as skins coating soil aggregates. In clay-rich soils, higher organic matter content and a greater concentration of O-alkyl C derived from polysaccharides may be expected compared to sandy soil, which are characterized by lower $\mathrm{C}$ contents and high concentrations of alkyl C (Rumpel and Kögel-Knabner, 2011). Aliphatic material may be responsible for the hydrophobicity of soils, which can lead to reduced microbial accessibility and therefore increased C storage (Lorenz et al., 2007). Many of the OM-matrix interactions are driven by expandable and non-expandable phyllosilicates, which interact with organic compounds through their large surface areas, micropores, and micro-aggregation, particularly in acid soils. In neutral and calcareous soils, polyvalent cations (especially $\mathrm{Ca}^{2+}$ ) predominate in the interaction mechanism, forming bridges between the largely negatively charged SOM and negatively charged phyllosilicates (Cotrufo et al., 2013). Short-order silicates, like allophane, provide some of the strongest organo-mineral interactions and stabilize both proteins and carbohydrate monomers, though their occurrence is very geographically restricted (Buurman et al., 2007; Dümig et al., 2012: Mikutta and Kaiser, 2011). Pedogenic oxides (for example iron oxyhydrates in rice paddies) usually act as a coating of soil mineral particles and stabilize carbon, contributing to a higher $\mathrm{C}$ storage and stability compared to other soils (Song et al., 2012).

Bioturbation (the mixing of soil by organisms) may further influence the amount as well as the chemical nature of 
Table 2. Management actions affecting soil nutrient cycles and their impact on ecosystem services.

\begin{tabular}{|c|c|c|c|c|}
\hline $\begin{array}{l}\text { Management ac- } \\
\text { tion or other driver } \\
\text { of change }\end{array}$ & $\begin{array}{l}\text { Provisioning service } \\
\text { impact }\end{array}$ & $\begin{array}{l}\text { Regulating service } \\
\text { impact }\end{array}$ & $\begin{array}{l}\text { Supporting service } \\
\text { impact }\end{array}$ & $\begin{array}{l}\text { Cultural service im- } \\
\text { pact }\end{array}$ \\
\hline $\begin{array}{l}\text { Intensive addition } \\
\text { of mineral fertiliz- } \\
\text { ers }\end{array}$ & $\begin{array}{l}\text { Increased food, fibre, } \\
\text { and feedstock produc- } \\
\text { tion }\end{array}$ & $\begin{array}{l}\text { Reduced water qual- } \\
\text { ity through eutroph- } \\
\text { ication, reduced air } \\
\text { quality through emis- } \\
\text { sion and volatilization } \\
\text { of reactive } \mathrm{N} \text { gases }\end{array}$ & $\begin{array}{l}\text { Increased primary } \\
\text { production; alter- } \\
\text { ation of the nutrient } \\
\text { and C cycling; pos- } \\
\text { sible reduction of } \\
\text { biodiversity }\end{array}$ & \\
\hline $\begin{array}{l}\text { Use of organic } \\
\text { soil amendments } \\
\text { (e.g. } \\
\text { composts manure, } \\
\text { biochar) }\end{array}$ & $\begin{array}{l}\text { Increased food, fibre, } \\
\text { and feedstock pro- } \\
\text { duction; may increase } \\
\text { water retention }\end{array}$ & $\begin{array}{l}\text { Increase } \mathrm{C} \text { sequestra- } \\
\text { tion }\end{array}$ & $\begin{array}{l}\text { Increase nutrient re- } \\
\text { tention }\end{array}$ & \\
\hline $\begin{array}{l}\text { Implementation of } \\
\text { no-till }\end{array}$ & & & $\begin{array}{l}\text { Increase nutrient re- } \\
\text { tention }\end{array}$ & \\
\hline $\begin{array}{l}\text { Precision agricul- } \\
\text { ture }\end{array}$ & $\begin{array}{l}\text { Increase efficient pro- } \\
\text { duction of food }\end{array}$ & $\begin{array}{l}\text { Reduced GHG emis- } \\
\text { sions per unit produc- } \\
\text { tion }\end{array}$ & $\begin{array}{l}\text { Reduce consumption } \\
\text { of water and nutrient } \\
\text { by improving use effi- } \\
\text { ciency }\end{array}$ & \\
\hline $\begin{array}{l}\text { Prescribed use of } \\
\text { fire for pasture } \\
\text { management }\end{array}$ & $\begin{array}{l}\text { Increase feedstock } \\
\text { production }\end{array}$ & $\begin{array}{l}\text { Increase } \mathrm{C} \text { sequestra- } \\
\text { tion by conversion to } \\
\mathrm{BC}\end{array}$ & $\begin{array}{l}\text { Reduce } \mathrm{N} \text { recycling } \\
\text { by storing black nitro- } \\
\text { gen }\end{array}$ & \\
\hline $\begin{array}{l}\text { Use of biological } \\
\text { soil supplements }\end{array}$ & $\begin{array}{l}\text { Stimulate productiv- } \\
\text { ity; act as fertilizers }\end{array}$ & $\begin{array}{l}\text { May improve pest and } \\
\text { disease control }\end{array}$ & $\begin{array}{l}\text { Improved nutrient cy- } \\
\text { cling }\end{array}$ & \\
\hline
\end{tabular}

soil C. It greatly influences the heterogeneity of soils by creating hotspots of carbon and biological activity. On biologically active sites, incorporation and transformation of organic compounds into soil is usually enhanced, leading to more organo-mineral interactions and increased C storage (Wilkinson et al., 2009).

Microbial decomposition of SOM may be stimulated by the input of labile (easily decomposed) organic matter through the priming effect (Jenkinson et al., 1971). Positive priming refers to greater mineralization of otherwise stable $\mathrm{C}$ through shifts in microbial community composition and activity (Fontaine et al., 2003). However, in some cases, the addition of organic matter to soil may also impede mineralization of native SOM (negative priming effect), thereby protecting SOM from its decomposition. Plant communities (Table 1) are the main controlling factors of these processes because they influence organic matter input and microbial activity by their effects on soil water, labile $\mathrm{C}$ input, $\mathrm{pH}$, and nutrient cycling (Kuzyakov et al., 2000).

By storing and cycling $\mathrm{C}$, nutrients, and water, soils provide supporting services like soil formation and nutrient and water retention, which underpin both primary production and landscape hydrology (the processes which deliver provisioning services such as food, fibre, and water; Table 1), in addi- tion to the regulating services such as climate regulation already discussed (Fig. 1). To ensure that soils continue to provide these key services, soil will require to be managed for $\mathrm{C}$ preservation - thus mitigating climate change - while simultaneously permitting continued SOM recycling (Table 1). Janzen (2006) pointed to this dilemma, that there is a tradeoff between improved soil fertility to support the provisioning services of food/timber production and the regulating service of soil carbon sequestration aiding climate regulation. Despite knowledge on which practices are likely to lead to improved SOC status, a better understanding of the controls on SOM distribution, stabilization, and turnover will help to better target these practices. This will be an important contribution to the mitigation of greenhouse gases, while assuring decomposition and, with it, the cycling of nutrients necessary to support food production. Table 1 summarizes management actions affecting the soil carbon cycle and their impacts on ecosystem services.

\section{Soils and nutrient cycles}

Soils support primary production among other services, which in turn delivers the provisioning services of food and fibre production (Table 2). As such, soils are vital to human- 

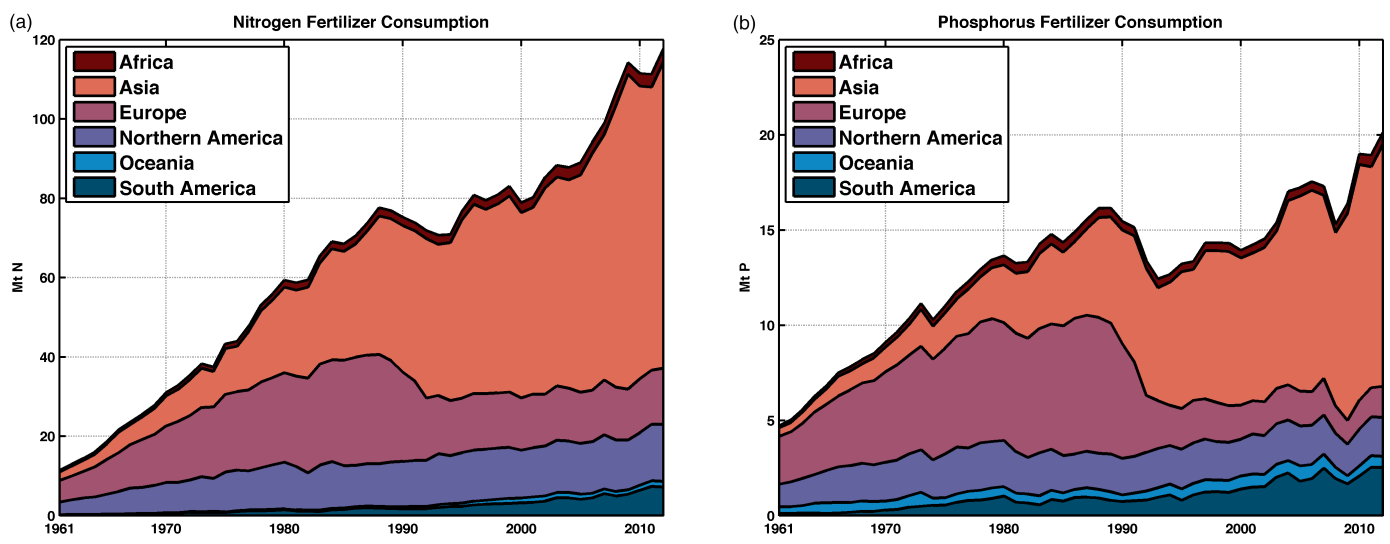

Figure 2. Global (a) nitrogen (N) and (b) phosphorus (P) fertilizer use between 1961 and 2012 split for the different continents in Mt P per year; plotted from FAOSTAT data (FAOSTAT, 2015).

ity since they provide essential nutrients, such as nitrogen $(\mathrm{N})$, phosphorus $(\mathrm{P})$, and potassium $(\mathrm{K})$ and many trace elements that support biomass production, which is essential for the supply of human and animal food, for energy and fibre production and (future) feedstock for the chemical industry (Table 2). Since the 1950s, higher biomass production and yield increases have been supported by fertilizers derived from mined minerals or industrial synthesis (Fig. 2). Intensification of agricultural practices and land use has in many regions resulted in a decline in the content of organic matter in agricultural, arable soils (Table 2; Matson et al., 1997; Smith et al., 2015). In some areas, extensive use of mineral fertilizers has led to atmospheric pollution, greenhouse gas emissions (e.g. $\mathrm{N}_{2} \mathrm{O}$, very important for climate regulation), water eutrophication, and human health risks (Galloway et al., 2008), thereby negatively affecting the regulating services of soil, air, and water quality (Table 2; Smith et al., 2013). During the 21 st century, it is likely that the human population and demand for food, feed, and energy will rise. In order to sustain biomass production in the future, and to avoid negative environmental impacts, fertile soils need to be preserved and soil fertility needs to be restored where lost. This can be done through both the recycling and accumulation of sufficient amounts of organic matter in soils (Janzen, 2006), through a combination of plant production and targeted additions of organic and mineral amendments to soils (see Sect. 2).

The soil function "fertility" refers to the ability of soil to support and sustain plant growth, which relates to making available N, P, other nutrients, water, and oxygen for root uptake. This is facilitated by (i) their storage in soil organic matter, (ii) nutrient recycling from organic to plant available mineral forms, and (iii) physical-chemical processes that control their sorption, availability, displacement, and eventual losses to the atmosphere and water (Table 2). Managed soils are a highly dynamic system and it is this very dynamism that makes the soil work and supply ecosystem services to humans. Overall, the fertility and functioning of soils strongly depend on interactions between the soil mineral matrix, plants, and microbes; these are responsible for both building and decomposing SOM, and therefore for the preservation and availability of nutrients in soils (Cotrufo et al., 2013). To sustain this service, the cycling of nutrients in soils must be preserved (Table 2).

After carbon, $\mathrm{N}$ is the most abundant nutrient in all forms of life, since it is contained in proteins, nucleic acids, and other compounds (Galloway et al., 2008). Humans and animals ultimately acquire their $\mathrm{N}$ from plants, which on land is mostly taken up in mineral form (i.e. $\mathrm{NH}_{4}^{+}$and $\mathrm{NO}_{3}^{-}$) from the soil. The parent material of soils does not contain significant amounts of $\mathrm{N}$ (most other nutrients such as P largely originate from the parent material). New $\mathrm{N}$ mostly enters the soil through the fixation of atmospheric $\mathrm{N}_{2}$ by a specialized group of microorganisms. However, the largest flux of $\mathrm{N}$ within the soils is generated through the continuous recycling of $\mathrm{N}$ internal to the plant-soil system: soil mineral $\mathrm{N}$ is taken up by the plant, is fixed into biomass, and eventually $\mathrm{N}$ returns in the form of plant debris to the soil. Here microorganisms decompose it, mineralizing part of the $\mathrm{N}$ and making it newly available for plant growth, while transforming the other part into SOM, which ultimately is the largest stock of stable $\mathrm{N}$ in soil. Generally, $\mathrm{N}$ cycles tightly in the system with minimal losses. Nitrogen is lost from the soil to the water system by leaching and to the atmosphere by gas efflux $\left(\mathrm{NH}_{4}, \mathrm{~N}_{2} \mathrm{O}\right.$, and $\left.\mathrm{N}_{2}\right)$. In most terrestrial natural ecosystems, $\mathrm{N}$ availability limits productivity. Through the cultivation of $\mathrm{N}_{2}$ fixing crops, the production and application of mineral $\mathrm{N}$ fertilizer, the increasing application of animal manure from livestock and bio-wastes, and the unintentional deposition of atmospheric reactive $\mathrm{N}$ (ultimately derived from industrialera human activities), humans have applied twice as much reactive $\mathrm{N}$ to soils as the $\mathrm{N}$ introduced by natural processes, significantly increasing biomass production on land (Vitousek and Matson, 1993; Erisman et al., 2008). In some regions of 

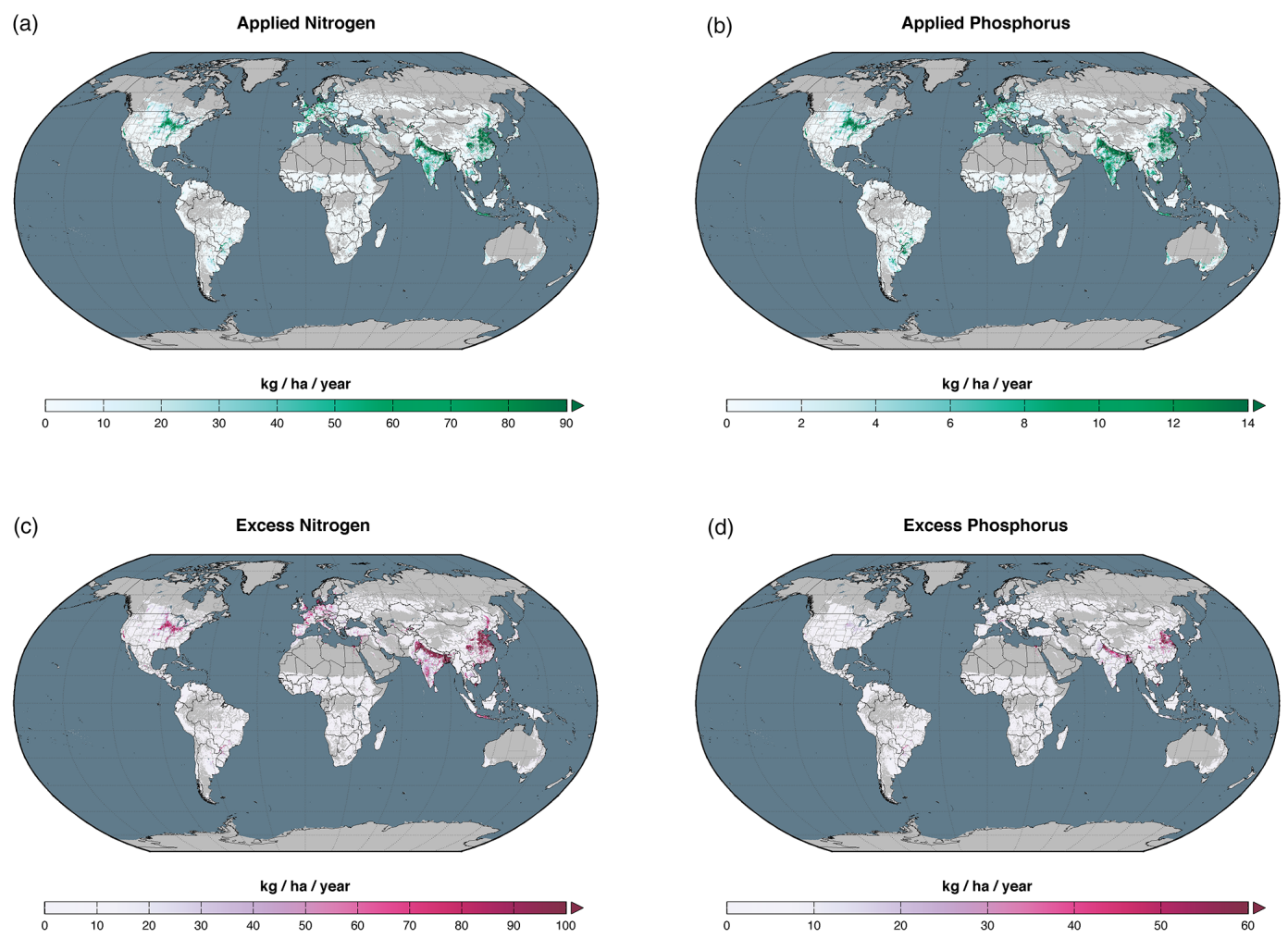

Figure 3. Applied and excess nitrogen and phosphorus in croplands. Nitrogen and phosphorus inputs and excess were calculated using a simple mass balance model (West et al., 2014), extended to include 175 crops. To account for both the rate and spatial extent of croplands, the data are presented as kilogram per hectare of the landscape. (a) Applied nitrogen, including N deposition; (b) applied phosphorus; (c) excess nitrogen; and (d) excess phosphorus.

the world, mineral fertilizer is applied in excess of plant requirement, but in other regions, in particular in Sub-Saharan Africa, where economic constraints limit the use of fertilizers, productivity is strongly limited by soil available $\mathrm{N}$ and other nutrients, notably $\mathrm{P}$ and $\mathrm{K}$ ( $\mathrm{N}$ and P; Fig. 3).

Phosphorus derived from parent material, through weathering, cycles internally in the plant-soil system between biochemical molecules (e.g. nucleic acid, phospholipids) and mineral forms after decomposition (e.g. $\mathrm{H}_{3} \mathrm{PO}_{4}$ ). In soils, $\mathrm{P}$ is among the most limiting of nutrients, since it occurs in small amounts and is only available to plants in its dissolved ionic forms, which promptly react with calcium, iron, and aluminium cations to form highly insoluble compounds. Largely in these forms, $\mathrm{P}$ is lost to the aquatic system through erosion and surface runoff. Losses may also occur in dissolved form, for instance via subsurface flow and groundwater (McDowell et al., 2015). An important form of loss is in the export of organic $\mathrm{P}$ in agricultural products. Due to widespread agricultural P deficiencies, humans started to mine "primary" $\mathrm{P}$ from guano or rock phosphate deposits and added it to soils in the form of mineral fertilizer (Fig. 2). This external input has led to positive agronomic $\mathrm{P}$ balances (MacDonald et al., 2011) and excesses of $\mathrm{P}$ and $\mathrm{N}$ in many regions (West et al., 2014; Fig. 3). There are large variations across the world, with high surpluses in the USA, Europe, and Asia and deficits in Russia, Africa, and South America (Fig. 3). Since plant P uptake is a relatively inefficient process with roughly $60 \%$ of the total P input to soils not taken up in the short term, a 3 -fold increase in the export of $\mathrm{P}$ to water bodies has been estimated, with significant impacts on water quality (Bennett et al., 2001).

Clearly, management practices need to be implemented that sustain, restore, or increase soil fertility and biomass production by promoting the accrual of SOM and nutrient recycling, applying balanced $\mathrm{C}$ amendments and fertilization of $\mathrm{N}, \mathrm{P}$, and other nutrients to meet plant and soil requirements, while limiting the addition of excess fertilizer and retaining nutrients in the soil-plant system (Table 2). C, N, and P cycling in soils is coupled by tight stoichiometric relationships (e.g. relatively fixed $\mathrm{C}: \mathrm{N}: \mathrm{P}$ in plants and microorganisms; Güsewell, 2004); thus their management needs to be studied in concert. Nutrient management has been extensively studied, with the aim of identifying and proposing management practices (e.g. precision agriculture) that improve nutrient use efficiency and productivity and reduce potentially harmful losses to the environment (Table 2; van Groenigen et al., 2010; Venterea et al., 2011). Yet, our ability to predict the ecosystem response to balanced fertilization is still 
Table 3. Soil functions related to the water cycle and ecosystem services.

\begin{tabular}{|c|c|c|c|}
\hline Soil function & Mechanism & Consequence & Ecosystem service \\
\hline Stores (storage) & $\begin{array}{l}\text { Water held in soil } \\
\text { pores supports plant } \\
\text { and microbial com- } \\
\text { munities }\end{array}$ & $\begin{array}{l}\text { Biomass production } \\
\text { Surface protection }\end{array}$ & $\begin{array}{l}\text { Food } \\
\text { Aesthetics } \\
\text { Erosion control }\end{array}$ \\
\hline $\begin{array}{l}\text { Accepts } \\
\text { (sorptivity) }\end{array}$ & $\begin{array}{l}\text { Incident water infil- } \\
\text { trates into soil with } \\
\text { excess lost as runoff }\end{array}$ & $\begin{array}{l}\text { Storm runoff reduc- } \\
\text { tion }\end{array}$ & $\begin{array}{l}\text { Erosion control } \\
\text { Flood protection }\end{array}$ \\
\hline $\begin{array}{l}\text { Transmits (hydraulic } \\
\text { conductivity) }\end{array}$ & $\begin{array}{l}\text { Water entering the soil } \\
\text { is redistributed and } \\
\text { excess is lost as deep } \\
\text { percolation }\end{array}$ & $\begin{array}{l}\text { Percolation to ground- } \\
\text { water }\end{array}$ & $\begin{array}{l}\text { Groundwater } \\
\text { recharge } \\
\text { Stream flow mainte- } \\
\text { nance }\end{array}$ \\
\hline $\begin{array}{l}\text { Cleans } \\
\text { (filtering) }\end{array}$ & $\begin{array}{l}\text { Water passing through } \\
\text { the soil matrix inter- } \\
\text { acts with soil particles } \\
\text { and biota }\end{array}$ & $\begin{array}{l}\text { Contaminants re- } \\
\text { moved by biological } \\
\text { degradation/retention } \\
\text { on sorption sites }\end{array}$ & Water quality \\
\hline
\end{tabular}

limited, and effectiveness and reliability would benefit from continued monitoring of efforts. Further benefits are anticipated from improved plant varieties with root morphologies that have better capacity to extract $\mathrm{P}$ from soils or use it more efficiently, perhaps in concert with mycorrhizal symbionts. Fertilization with nutrients other than $\mathrm{N}$ and $\mathrm{P}$ has been less well explored within the realm of understanding soil organic matter responses to agricultural $\mathrm{C}$ inputs and the potential to restore and increase soil organic matter (e.g. Lugato et al., 2006). Hence, we stress the importance of an integrated approach to nutrient management, which supports plant productivity while preserving or enhancing SOM stocks, and reducing nutrient losses to the atmosphere or water resources. Several issues exist where prediction and optimization of performance would benefit from relevant and continued data acquisition for the range of climate and environmental and agro-ecological conditions. Table 2 summarizes some management actions affecting soil nutrient cycles and their impacts on ecosystem services.

\section{Soils and the water cycle}

Soils provide important ecosystem services through their control on the water cycle. These services include provisioning services of food and water security, regulating services associated with moderation, and purification of water flows, and they contribute to the cultural services of landscapes/water bodies that meet recreation and aesthetic values (Table 3; Dymond, 2014). At the pedon to hillslope scale, water stored in soil is used for evapotranspiration and plant growth that supplies food, stabilizes the land surface to prevent erosion, and regulates nutrient and contaminant flow. At a catchment and basin scale, the capacity of the soil to infil- trate water attenuates stream and river flows and can prevent flooding, while water that percolates through soil can replenish groundwater that can maintain water supplies and sustain surface water ecosystems while promoting a continued flow during periods of reduced precipitation (Guswa et al., 2014).

The soil functions of accepting, storing, transmitting and cleaning of water shown in Table 3 are inter-related. Soil water storage depends on the rate of infiltration into the soil relative to the rate of precipitation. Soil hydraulic conductivity redistributes water within and through the soil profile. The infiltration rate and hydraulic conductivity both depend on the water stored in the soil. The initially high rate of infiltration into dry soil declines as the soil water content increases and water replaces air in the pore space. Conversely, hydraulic conductivity increases with soil moisture content as a greater proportion of the pores are transmitting water. Water content and transmission times are also important to the filtering function of soil because contact with soil surfaces and residence time in soil are important controls on contaminant supply and removal (McDowell and Srinivasan, 2009).

The quantity of water which a soil can store depends on the thickness of the soil layer, its porosity, and soil matrixwater physical interactions. The latter are expressed as a water retention curve, the relationship between the soil water content and the forces holding it in place. The porosity and water retention curve are in turn influenced primarily by the particle size distribution and the soil bulk density, but also by the amount of SOM and the macropores created by biotic activity (Kirkham, 2014).

Optimum growth of most plants occurs when roots can access both oxygen and water in the soil. The soil must therefore infiltrate water, drain quickly from saturation to allow air to reach plant roots, and retain and redistribute water for plant use. An ideal soil for plant production depends on the 
Table 4. Management actions affecting the soil water cycle and their impact on ecosystem services.

\begin{tabular}{|c|c|c|c|c|}
\hline $\begin{array}{l}\text { Management action or } \\
\text { other driver of change }\end{array}$ & $\begin{array}{l}\text { Provisioning service } \\
\text { impact }\end{array}$ & $\begin{array}{l}\text { Regulating service im- } \\
\text { pact }\end{array}$ & $\begin{array}{l}\text { Supporting service im- } \\
\text { pact }\end{array}$ & Cultural service impact \\
\hline $\begin{array}{l}\text { Land use change (in- } \\
\text { crease change of agri- } \\
\text { cultural to urban) }\end{array}$ & $\begin{array}{l}\text { Decreased biomass; de- } \\
\text { creased availability of } \\
\text { water for agricultural } \\
\text { use }\end{array}$ & $\begin{array}{l}\text { Increased impervious } \\
\text { surface; decreased } \\
\text { infiltration, storage, } \\
\text { soil-mediated } \\
\text { regulation }\end{array}$ & $\begin{array}{l}\text { Decreased } \text { genetic } \\
\text { diversity; reduction } \\
\text { of rainfall recycling, } \\
\text { e.g. in the tropics }\end{array}$ & $\begin{array}{l}\text { Decreased natural envi- } \\
\text { ronment }\end{array}$ \\
\hline $\begin{array}{l}\text { Land use change } \\
\text { (increase change of } \\
\text { arable to intensive } \\
\text { grassland) }\end{array}$ & $\begin{array}{l}\text { Increased yield of ani- } \\
\text { mal over vegetable pro- } \\
\text { tein }\end{array}$ & $\begin{array}{l}\text { Increased C sequestra- } \\
\text { tion; greater require- } \\
\text { ment of water; stress } \\
\text { on ecosystem health of } \\
\text { downstream waterways }\end{array}$ & $\begin{array}{l}\text { Increased genetic di- } \\
\text { versity associated with } \\
\text { mixed pastures }\end{array}$ & $\begin{array}{ll}\text { Change from tra- } & \text { titional values and } \\
\text { ditic value } & \\
\text { aesthetic } & \end{array}$ \\
\hline Irrigation (increase) & $\begin{array}{l}\text { Increased biomass over } \\
\text { dryland agriculture; de- } \\
\text { creased availability of } \\
\text { water for urban use }\end{array}$ & $\begin{array}{l}\text { Increased C sequestra- } \\
\text { tion, but decreased fil- } \\
\text { tration potential }\end{array}$ & $\begin{array}{l}\text { Improved habitat for } \\
\text { plant species }\end{array}$ & $\begin{array}{l}\text { Infrastructure alters } \\
\text { landscape decreasing } \\
\text { spiritual connection } \\
\text { with catchment }\end{array}$ \\
\hline $\begin{array}{l}\text { Drainage (increasing } \\
\text { in marginal land) }\end{array}$ & $\begin{array}{l}\text { Decreased soil sat- } \\
\text { uration; } \\
\text { biomass; removal of } \\
\text { wetlands }\end{array}$ & $\begin{array}{l}\text { Decreased C seques- } \\
\text { tration, denitrification, } \\
\text { and flood attenuation }\end{array}$ & $\begin{array}{l}\text { Better habitat for } \\
\text { productive grassland } \\
\text { plants, but loss of } \\
\text { genetic diversity }\end{array}$ & $\begin{array}{l}\text { Decreased recreational } \\
\text { potential (e.g. eco- } \\
\text { tourism) }\end{array}$ \\
\hline
\end{tabular}

climatic conditions. Soil structural stability and porosity are also important for the infiltration of water into soil. In addition to soil texture, organic matter improves soil aggregate stability (Das et al., 2014). While plant growth and surface mulches can help protect the soil surface, a stable, wellaggregated soil structure that resists surface sealing and continues to infiltrate water during intense rainfall events will decrease the potential for downstream flooding resulting from rapid overland flow. Porosity (especially macropores of a diameter $\geq 75 \mu \mathrm{m}$ ) controls transmission of water through the soil. In addition to total porosity, the continuity and structure of the pore network are as important to these functions as they are in filtering out contaminants in flow. Furthermore, the soil must support biota that will degrade the compounds of interest or have sorption sites available to retain the chemical species. Soil organic matter is important for these roles and, together with mineral soil (especially the clay fraction), provides sorption sites (Bolan et al., 2011). Flow through macropores, which bypass the soil matrix, where biota and sorption sites are generally located, can quickly transmit water and contaminants through the soil to groundwater or artificial drains, but for filtering purposes, a more tortuous route through the soil matrix is more effective (McDowell et al., 2008). There are multiple other links between soil biota and soil water, with water potential in particular having a pivotal role in the structure, growth, and activity of the soil microbial community (Parr et al., 1981).

Management of soil alters the ecosystem services provided by water (Table 4). Soil conservation and sustainable management practices to combat desertification help to retain soil organic matter, structural stability, infiltration, and profile water holding capacity. The promotion of soil as a $\mathrm{C}$ sink to offset greenhouse gas emissions generally helps to maintain or improve soil hydrological functions as well. Deforestation, overgrazing, and excessive tillage of fragile lands, however, will lead to soil structural deterioration and a loss of infiltration, water retention, and surface water quality (Table 4; Steinfeld et al., 2006). Anthropogenic modifications to the water cycle can aid soil function. In dry regimes, inadequate soil moisture can be mitigated through supplementary irrigation, and where waterlogging occurs it can be relieved by land drainage. However, irrigation and drainage can have consequences for water regulation services. Irrigation that enables a shift to intensive land use can increase the contaminant load of runoff and drainage (Table 4; McDowell et al., 2011). Furthermore, drainage of wetland soils has been shown to reduce water and contaminant storage capacity in the landscape and can increase the potential for downstream flooding, as well as increasing the potential for GHG emissions due to the rapid decomposition of SOC in soil and dissolved organic C in drainage water (IPCC, 2013). The removal of surface or groundwater for irrigation disrupts the natural water cycle and may stress downstream ecosystems and communities. Irrigation of agricultural lands accounts for about $70 \%$ of ground and surface water withdrawals, and in some regions competition for water resources is forcing irrigators to tap unsustainable sources. Irrigation with wastewater may conserve fresh water resources, but the fate of waterborne contaminants in soil and crops is a potential concern (Sato et al., 2013). 


\section{Soils as a habitat for organisms and as a genetic resource}

Soils represent a physically and chemically complex and heterogeneous habitat supporting a high diversity of microbial and faunal taxa. For example, $10 \mathrm{~g}$ of soil contains about $10^{10}$ bacterial cells, representing more than $10^{6}$ species (Gans et al., 2005). Up to 360000 species of animals live predominantly in the soil - a large fraction of all animal species (Decaëns et al., 2006). These complex communities of organisms play critical roles in sustaining soil and wider ecosystem functioning, thus conferring a multitude of benefits to global cycles and human sustainability. Specifically, soil biodiversity contributes to food and fibre production, and is an important regulator of other soil services including greenhouse gas emissions, water purification (Table 5; Bodelier, 2011), and supporting services such as nutrient cycling. Stocks of soil biodiversity represent an important biological and genetic resource for biotechnological exploitation. Previous methodological challenges in characterizing soil biodiversity are now being overcome through the use of molecular technologies, and currently significant progress is being made in opening the "black box" of soil biodiversity (Allison and Martiny, 2008) with respect to providing fundamental information on normal operating ranges of the biodiversity under different soil, climatic, and land use scenarios. Addressing these knowledge gaps is of fundamental importance, firstly as a prelude to understanding wider soil processes, but also to better inform the likely consequences of land use or climatic change on both biodiversity and soil ecosystem services.

The development of molecular technologies has led to a surge in studies characterizing soil biodiversity at different scales - from large landscape scale surveys to specific, locally focused studies using manipulation, or contrasting of specific land uses. The large-scale surveys yield the broader picture, and conclusions are emerging identifying the importance of soil parameters in shaping the biodiversity of soil communities (Fierer and Jackson, 2006). In essence, the same geological, climatic, and biotic parameters which ultimately dictate the supporting service of soil formation are also implicated in shaping the communities of soil biota, thus regulating the spatial structure of soil communities observed over large areas (Griffiths et al., 2011). Locally focused experimentation typically reveals more specific changes with respect to local land use or climate. Most studies have focused on assessing one component of soil diversity. Nextgeneration high throughput sequencing now allows the analyses of "whole soil food webs", permitting a thorough interrogation of trophic and co-occurrence interaction networks. The challenge is to consolidate both approaches at various scales in order to understand the differing susceptibility of global soil biomes to change.

It is essential to link these new biodiversity measures to specific soil functions in order to understand the pivotal roles of soil organisms in mediating soil services. The develop- ment of in situ stable isotope tracer methods (e.g. Radajewski et al., 2000) to link substrate use to the identified active members serves to clarify the physiological activity of these organisms. Additionally, whole-genome shotgun metagenomic sequencing is now becoming an increasingly cost-effective approach to assessing the biodiversity of functional genes in soils (Fierer et al., 2013), potentially allowing for a traitbased rather than taxon-based approach to understanding soil biodiversity, akin to recent approaches applied to larger and more readily functionally understood organisms above ground. It is becoming increasingly apparent that functionality and biodiversity co-vary with other environmental parameters. Thus manipulative experimentation is required to determine the fundamental roles of soil biodiversity versus other co-varying factors in driving soil functionality. Table 5 summarizes management actions affecting the soil biota and their impacts on ecosystem services.

\section{Knowledge gaps and research needs concerning soil carbon, nutrient, and water cycles, and the role of soil biodiversity}

Soil carbon cycle: Substantial progress has been made in recent years towards more fundamental understanding of the processes controlling soil $\mathrm{C}$ storage and in improving and deploying predictive models of soil $\mathrm{C}$ dynamics that can guide decision makers and inform policy. However, it is equally true that many new (and some old) gaps in our knowledge have been identified and research needs articulation. New research on soil $\mathrm{C}$ dynamics has been driven in part by increasing awareness of (1) the importance of small-scale variability for microbial C turnover (Vogel et al., 2014), (2) interactions between the $\mathrm{C}$ cycle with other biogeochemical cycles (Gärdenäs et al., 2011), and (3) the importance of soil $\mathrm{C}$, not only at the field scale but also at regional to global scales (Todd-Brown et al., 2013). The most cited gaps in basic knowledge include plant effects on SOM storage and turnover; controls on microbial efficiency of organic matter processing, including biodiversity, association/separation of organic matter, and decomposing microbial communities in the mineral soil matrix (Bardgett et al., 2008); the role of soil fauna in controlling carbon storage and cycling, dynamics of dissolved organic carbon, and its role in determining C storage and decomposition (Moore et al., 2031; Butman et al., 2014); black C stabilization and interactions of black C including biochar with native soil $\mathrm{C}$ and mineral nutrients; and the role of soil erosion in the global C cycle (Quinton et al., 2010). For predictive modelling and assessment, the most frequently cited knowledge gaps are closer correspondence of measured and modelled SOM fractions (Zimmermann et al., 2007), improved modelling of $C$ in subsurface soil layers, distributed soil $\mathrm{C}$ observational and monitoring networks for model validation, more realistic and spatially resolved repre- 
Table 5. Management actions affecting the soil biota and their impacts on ecosystem services.

\begin{tabular}{|c|c|c|c|c|}
\hline $\begin{array}{l}\text { Management action or } \\
\text { other driver of change }\end{array}$ & $\begin{array}{l}\text { Provisioning service } \\
\text { impact }\end{array}$ & $\begin{array}{l}\text { Regulating service } \\
\text { impact }\end{array}$ & $\begin{array}{l}\text { Supporting } \\
\text { impact }\end{array}$ & $\begin{array}{l}\text { Cultural service } \\
\text { impact }\end{array}$ \\
\hline $\begin{array}{l}\text { Land use change of nat- } \\
\text { ural vegetation to agricul- } \\
\text { tural intensification }\end{array}$ & $\begin{array}{l}\text { Changed genetic } \\
\text { resources; changed } \\
\text { production of (pre- } \\
\text { cursors to) industrial } \\
\text { and pharmaceutical } \\
\text { products }\end{array}$ & $\begin{array}{l}\text { Decreased C seques- } \\
\text { tration; changed pest } \\
\text { and disease control }\end{array}$ & $\begin{array}{l}\text { Changed elemental } \\
\text { transformation }\end{array}$ & $\begin{array}{l}\text { Changed di- } \\
\text { versity of soil } \\
\text { organisms (e.g. } \\
\text { elimination } \\
\text { of some soil } \\
\text { organisms) }\end{array}$ \\
\hline Use of organic amendments & $\begin{array}{l}\text { Increased genetic } \\
\text { resources, decreased } \\
\text { production of (pre- } \\
\text { cursors to) industrial } \\
\text { and pharmaceutical } \\
\text { products }\end{array}$ & $\begin{array}{l}\text { Increased } \mathrm{C} \text { seques- } \\
\text { tration }\end{array}$ & $\begin{array}{l}\text { Increased soil for- } \\
\text { mation, increased } \\
\text { primary production } \\
\text { by phototrophs, } \\
\text { changed elemental } \\
\text { transformation }\end{array}$ & $\begin{array}{l}\text { Increase in soil } \\
\text { organisms }\end{array}$ \\
\hline $\begin{array}{l}\text { Use of broad spectrum } \\
\text { bioactive agrochemicals }\end{array}$ & $\begin{array}{l}\text { Decreased genetic } \\
\text { resources, decreased } \\
\text { production of (pre- } \\
\text { cursors to) industrial } \\
\text { and pharmaceutical } \\
\text { products }\end{array}$ & $\begin{array}{l}\text { Possible decreased } \\
\text { waste decomposition } \\
\text { and detoxification }\end{array}$ & $\begin{array}{l}\text { Decreased primary } \\
\text { production by pho- } \\
\text { totrophs, changed } \\
\text { elemental transforma- } \\
\text { tion }\end{array}$ & $\begin{array}{l}\text { Decreased di- } \\
\text { versity of soil } \\
\text { organisms (e.g. } \\
\text { elimination } \\
\text { of some soil } \\
\text { organisms) }\end{array}$ \\
\hline $\begin{array}{l}\text { Pollution by heavy metals } \\
\text { or xenobiotics }\end{array}$ & $\begin{array}{l}\text { Decreased genetic } \\
\text { resources, decreased } \\
\text { production of (pre- } \\
\text { cursors to) industrial } \\
\text { and pharmaceutical } \\
\text { products }\end{array}$ & $\begin{array}{l}\text { Possible decreased } \\
\text { waste decomposition } \\
\text { and detoxification }\end{array}$ & $\begin{array}{l}\text { Decreased primary } \\
\text { production by pho- } \\
\text { totrophs, changed } \\
\text { elemental transforma- } \\
\text { tion }\end{array}$ & $\begin{array}{l}\text { Decreased di- } \\
\text { versity of soil } \\
\text { organisms (e.g. } \\
\text { elimination } \\
\text { of some soil } \\
\text { organisms) }\end{array}$ \\
\hline $\begin{array}{l}\text { Climate change (global } \\
\text { warming) }\end{array}$ & & $\begin{array}{l}\text { Possible decreased } \mathrm{C} \\
\text { sequestration }\end{array}$ & $\begin{array}{l}\text { Changed elemental } \\
\text { transformation }\end{array}$ & \\
\hline
\end{tabular}

sentation of soil $\mathrm{C}$ in global-scale models, and the response to climatic extremes (Reichstein et al., 2013).

Soil nutrient cycles: In the second half of the 20th century, higher biomass yields were supported by higher use of fertilizer $(\mathrm{N}, \mathrm{P})$ inputs. Today, at the beginning of the $21 \mathrm{st}$ century, this is not considered sustainable. Alternatives are needed that will use inherent soil fertility and improved resource use efficiencies, and to prevent losses of $\mathrm{N}$ and P. Examples in agriculture include ecological intensification and new crop varieties with improved ability to extract $\mathrm{P}$ and use from soils. At the food system level, more effective nutrient management would benefit from a focus on a " $5 \mathrm{R}$ strategy": (1) realign $\mathrm{P}$ and $\mathrm{N}$ inputs, (2) reduce $\mathrm{P}$ and $\mathrm{N}$ losses to minimize eutrophication impacts, (3) recycle the $\mathrm{P}$ and $\mathrm{N}$ in bio-resources, (4) recover $\mathrm{P}$ (and $\mathrm{N}$ ) from wastes into fertilizer, and (5) redefine use and use efficiency of $\mathrm{N}$ and $\mathrm{P}$ in the food chain including diets and regional and spatial variability (e.g. Snyder et al., 2014).

Soil water: The soil management practices that maintain the ecosystem services of food and water provision, flow regulation, water purification, and aesthetic value within the soil and water cycle are well known. However, their appli- cation is not universal and poor management leads to a loss of function. Under scenarios of increased climatic variability with more extremes of precipitation and increased severity of droughts, soil functions will be stressed and the level of good soil management will be required to improve (Walthall et al., 2012). Research into these interactions, as well as future proofing of current good practice, is required.

Soil biota: Despite recent advances in knowledge regarding stocks and changes in soil biodiversity, global-scale syntheses are still largely absent. Indeed, many of these highly pertinent issues were raised more than 20 years ago (Furusaka, 1993), and to date none of these factors have been unravelled fully. Key barriers to syntheses are the lack of concerted soil surveys addressing multiple functions with standardized methodologies. New technologies for soil biodiversity assessment generate large data sets of gene sequences which are typically archived in publicly accessible databases. The adoption of such approaches for soil function measurements alongside deployment of agreed standard operating procedures (e.g. as developed in the recent, EUfunded EcoFINDERS project) could serve to address these gaps. Ultimately, new methods are revealing the high sensi- 
tivity of change in soil biological and genetic resources from threats such as management, and we now need to recognize the distinct types of organisms found in different soils globally and understand their functional roles in order to predict vulnerability of these resources to future change.

\section{Recommendations for management activities to support the continued delivery of ecosystem services from soils}

Best management practices that support one facet of soil functioning tend to also support others. Building SOM, for example, enhances soil C, soil nutrient status, improves water holding capacity, and supports soil biota (Lal, 2004; Smith, 2012). Similarly, preservation of natural ecosystems, and prevention of degradation or conversion to intensive agriculture, almost always benefits soil $\mathrm{C}$, nutrients, water, and biota. These synergies, and the fundamental role of soil, make the goal of supporting soil function more straightforward than the goal of maximizing multiple ecosystem services, which often involves trade-offs (Robinson et al., 2013; Smith et al., 2013). For example, in terms of the provisioning service of food, the highest per-area yields are often obtained under intensive cropping, with large external inputs of mineral fertilizer, other agro-chemicals (such a pesticides and herbicides), and sometimes water through irrigation (West et al., 2014), with the most intensive forms of agriculture occurring in greenhouses, where external inputs of fertilizers, water, and energy can be extremely high (Liu et al., 2008). Though intensive cropping produces high per-area yields, it is not the best management system for a range of other ecosystem services, potentially adversely affecting supporting services (e.g. soil formation through erosion), regulating services (e.g. climate regulation through greenhouse gas emissions; air, water, and soil quality through leaching of agrochemicals; pollination through adverse impacts on pollinators), and cultural services (e.g. reduced aesthetic value of the landscape through large-scale monoculture; Smith et al., 2013). Balancing the trade-offs between different ecosystems services is, therefore, more difficult than designing management strategies that support soil $\mathrm{C}$, nutrients, water, and biota. Tables 1, 2, 4, and 5 present some examples of management activities that affect a range of soil functions, and a number of beneficial management actions occur in most/all of the tables. The most important of these beneficial management activities are described below.

\subsection{Land cover and use change}

A number of meta-analyses (Wei et al., 2014; Guo and Gifford, 2002; Don et al., 2011) show that natural systems lose carbon when converted to agriculture, with the exception of forest to pasture conversion, where some studies indicate carbon gain (Guo and Gifford, 2002) while others indicate carbon loss (Don et al., 2011). Given the link between organic matter and soil carbon, nutrients, water, and biota, conversion of natural systems to agriculture is likely to adversely impact all of these factors. Protection of natural ecosystems, therefore, benefits soil carbon, nutrients, water, and biota. Rewilding of surplus agricultural land would be expected to enhance soil carbon, nutrients, water, and biota, as seen for set-aside land or reforestation of former cropland (Don et al., 2011). In the absence of land cover/land use change, improved management of agricultural soils can improve soil carbon, nutrient, water, and biota (Smith et al., 2015), as described below.

\subsection{Improved agricultural management}

Reducing soil disturbance (e.g. through reduced or zerotillage) is often done to improve soil moisture retention to enhance soil function, and can also increase SOC stocks (West and Post, 2002; Ogle et al., 2005), though the $\mathrm{C}$ benefits of no-till may be limited to the top $30 \mathrm{~cm}$ of soil and some authors argue that the $\mathrm{C}$ benefits have been overstated (Powlson et al., 2014). Baker et al. (2006) found similar soil C in conventional and no-till systems, suggesting that $\mathrm{C}$ accumulation is occurring at different depths in the soil profile under different management schemes. Given the tight coupling of soil $\mathrm{C}$ and $\mathrm{N}$, increased organic matter also tends to increase nutrient supply, and also enhances water holding capacity (Lal, 2004) which in turn improves the delivery of ecosystem services, and can increase soil biota. Zero tillage also gives rise to greater earthworm and arthropod populations (House and Parmelee, 1985). Perennial crops also reduce the need for annual tillage, and can provide similar benefits. Cultivation of perennial plants with improved rooting systems is likely to increase soil C stocks in C-depleted subsoil horizons (Kell, 2012). Land use change, such as removal of perennial plants and subsequent cultivation, were found to affect both shortlived and long-lived C pools (Beniston et al., 2014).

Maintaining ground cover through improved residue management, and use of cover crops during traditional bare fallow periods, helps to improve $\mathrm{C}$ returns to the soil, prevent erosion and surface sealing, maintain soil nutrients and soil moisture, and support an active level of soil biota (Lal, 1997). Similar benefits can be achieved through well-designed rotations and use of perennial crops or agroforestry (e.g. Mbow et al., 2014).

Use of organic amendments increases SOM content (Lal, 2004; Smith, 2012; Gattinger et al., 2012), which, as described above, benefits soil C, nutrients, water, and biota. Organic amendments traditionally include crop residues, animal manures, slurries, and composts. These organic matter additions were found to improve $\mathrm{C}$ storage and other regulating ecosystem services if repeated regularly. Recent developments, such as the use of biochar or hydrochar from the pyrolysis or hydrothermal carbonization of crop residues or other biomass, can increase SOC stocks and can also reduce soil $\mathrm{N}_{2} \mathrm{O}$ emissions and enhance soil fertility (Zhang et al., 2010), which could be effective over multiple years (Liu 
et al., 2014). However, the properties of these materials and their net effect on ecosystem services are strongly dependent on production conditions (Wiedner et al., 2013; Naisse et al., 2015). Soil amendment with compost and biochar or their mixture may be particularly useful for increasing the regulating and supporting services of degraded soils (Ngo et al., 2014). Biochar, in conjunction with bioenergy production, is at this stage one of the most promising technologies for achieving the large-scale negative carbon emissions required by the middle of the century to prevent global mean temperatures from increasing above $2{ }^{\circ} \mathrm{C}$, though this is controversial (Fuss et al., 2014).

Optimized timing and rate of fertilizer application: Intensification has increased annual global flows of $\mathrm{N}$ and $\mathrm{P}$ to more than double natural levels (Matson et al., 1997; Smil, 2000; Tilman et al., 2002). In China, $\mathrm{N}$ inputs to agriculture in the 2000s were twice that in 1980s (State Bureau of Statistics-China, 2005). Optimizing the timing and rate of fertilizer applications ensures that the nutrients are available in the soil at a time when the plant is able to take them up, which limits nutrient loss, hence reducing the risk of water pollution and downstream eutrophication (Carpenter et al., 1998). Fertilizer decision support tools can help in implementing optimized nutrient management, as can soil testing (to establish soil nutrient status before fertilization), and precision farming, to ensure that nutrient additions are targeted where needed. Subsurface application of slurries to reduce ammonia volatilization can increase nitrous oxide emissions, so there can be trade-offs associated with this practice (Sutton et al., 2007).

Optimized use of agrochemicals: Reduction in use of broad spectrum bioactive agrochemicals will benefit soil biota. The under-application of pesticides and herbicides could also plausibly have net negative environmental impact, if it means that more land needs to be brought into production (Carlton et al., 2010, 2012). Optimization of agrochemical applications will also reduce water pollution through leaching.

Water management: Irrigation of dryland agriculture can increase productivity and $\mathrm{C}$ returns to the soil, with the benefits to soil carbon, nutrients, water, and biota discussed above, but it can decrease filtration potential and increase the risk of soil salinization (Ghassemi et al., 1995; Setia et al., 2011). In waterlogged marginal lands, drainage can increase productivity and thereby increase carbon returns to the soil while at the same time decreasing methane and nitrous oxide emissions. If wetland soils are drained, oxidation of organic soils will lead to large losses of soil $\mathrm{C}$ and the nutrients associated with it, decreasing the ability of these soils to carry out services like water purification (e.g. through denitrification). Drainage of peatlands has been associated with increased runoff and flood risk (Ballard et al., 2012). In terms of biodiversity, productivity of drained marginal lands can increase at the expense of plant genetic diversity.

Improved grazing management (e.g. optimized stocking density) can reduce soil degradation and thereby maintain and enhance organic matter content (McSherry and Ritchie, 2013), benefiting soil C, nutrients, water, and biota as described above. Higher productivity and deep-rooted grasses can similar effects (Kell, 2012), while also modifying water use efficiency, but potentially at the expense of plant genetic diversity. Reduction in grazing density can reduce soil compaction and therefore increase infiltration and water storage and reduce the risk of runoff and flooding downstream (Marshall et al., 2009). Fire management can also increase soil C and nutrient status of soils (e.g. Certini, 2005).

\section{Conclusions}

Many practices are known to enhance all or most of the functions of soils considered in this review, which is encouraging for our efforts to protect soils into the future. Soils are complex, there are still knowledge gaps (outlined in Sect. 6), and fundamental research is still needed to better understand the relationships between different facets of soils and the array of ecosystem services they underpin. There is a tendency to dwell on the complexity and knowledge gaps rather than to focus on what we do know and how this knowledge can be put to use to improve the delivery of ecosystem services. While more knowledge is required on where specific agricultural systems are best placed to utilize and deliver ecosystem services most efficiently in order to protect and enhance our soils in the long term, best practices are well characterized and many can be implemented immediately. Despite a growing population and increasing demands for resources, enough is known to discriminate the extremes of beneficial and detrimental agricultural practices, as well as their interactions with different types of soils. A significant challenge is to find effective ways to share this knowledge with soil managers and policy makers, so that best management can be implemented. A key element of this knowledge exchange must be in raising awareness of the ecosystems services underpinned by soils and thus the natural capital they provide (Robinson et al., 2013). We know enough to start moving in the right direction, while we conduct research to fill in our knowledge gaps. Therefore, a challenge to soil scientists is to better communicate what we do know while we carry out research to better understand the things that we do not know. The lasting legacy of the International Year of Soils in 2015 should be for soil scientists to work together with policy makers and land managers in order to put soils at the centre of environmental policy making and land management decisions.

Acknowledgements. The input from P. Smith and P. J. Kuikman contributes to the EU-funded FP7 project SmartSOIL (grant agreement no. 289694), and that from P. Smith and R. I. Griffiths to the NERC-funded U-Grass project (NE/M016900/1). The input from P. C. West and J. S. Gerber was supported by the Gordon and Betty Moore Foundation, and that from P. Smith, J. S. Gerber, and 
P. C. West contributes to the Belmont Forum/FACCE-JPI-funded DEVIL project (NE/M021327/1). Input from G. Pan was supported by funding from the Priority Academic Program Development of Jiangsu Higher Education Institutions, China. J. I. House was funded by a Leverhulme early career research fellowship.

Edited by: K. Kalbitz

\section{References}

Aerts, R., Wallen, B., and Malmer, N.: Growth-limiting nutrients in sphagnum-dominated bogs subject to low and high atmospheric nitrogen supply, J. Ecol., 80, 131-140, 1992.

Alberti, G., Vicca, S., Inglima, I., Belelli-Marchesini, L., Genesio, L., Miglietta, F., Marjanovic, H., Martinez, C., Matteucci, G., D’Andrea E., Peressotti, A., Petrella, F., Rodeghiero, M., and Cotrufo, M. F.: Soil C:N stoichiometry controls carbon sink partitioning between above-ground tree biomass and soil organic matter in high fertility forests, iForest, 8, 195-206, doi:10.3832/ifor1196-008, 2014.

Allison, S. D. and Martiny, J. B. H.: Resistance, resilience, and redundancy in microbial communities, P. Natl. Acad. Sci. USA, 105, 11512-11519, 2008.

Averill, C., Turner, B. L., and Finzi, A. C.: Mycorrhiza-mediated competition between plants and decomposers drives soil carbon storage, Nature, 505, 543-545, 2014.

Baker, J. M., Ochsner, T. E., Venterea, R. T., and Griffis, T. J.: Tillage and soil carbon sequestration - What do we really know?, Agric. Ecosyst. Env., 118, 1-5, 2006.

Ballard, C. E., McIntyre, N., and Wheater, H. S.: Effects of peatland drainage management on peak flows, Hydrol. Earth Syst. Sci., 16, 2299-2310, doi:10.5194/hess-16-2299-2012, 2012.

Bardgett, R. D., Freeman, C., and Ostle, N. J. Microbial contributions to climate change through carbon cycle feedbacks, ISME J., 2, 805-814, 2008.

Batjes, N. H.: Total carbon and nitrogen in the soils of the world, European J. Soil Sci., 47, 151-163, 1996.

Beniston, J. W., DuPont, S. T., Glover, J. D., Lal, R., and Dungait, J. A. J.: Soil organic carbon dynamics 75 years after land-use change in perennial grassland and annual wheat agricultural systems, Biogeochem., 127, 37-49, 2014.

Bennett, E. M., Carpenter, S. R., and Caraco, N. F.: Human impact on erodable phosphorus and eutrophication: a global perspective. Increasing accumulation of phosphorus in soil threatens rivers, lakes, and coastal oceans with eutrophication, BioSci., 51, 227234, 2001.

Bird, M. I., Wynn, J. G., Saiz, G., Wurster, C. M., and McBeath, A.: The Pyrogenic Carbon Cycle, Ann. Rev. Earth Planet. Sci., 43, 9.1-9.26, doi:10.1146/annurev-earth-060614-105038, 2015.

Blum, W. E. H.: Land degradation, in: Land degradation - Contributions to the International Workshop "Land degradation", 5-6 December 2002, Ispra, Italy, edited by: Jones, R. J. A. and Montanarella, L., 2002.

Bodelier, P. L. E.: Toward understanding, managing, and protecting microbial ecosystems, Front. Microbiol., 2, 80, doi:10.3389/fmicb.2011.00080, 2011.

Bolan, N. S., Adriano, D. C., Kunhikrishnan, A., James, T., McDowell, R. W., and Senesi, N.: Dissolved organic matter: bio- geochemistry, dynamics and environmental significance in soils, Adv. Agron., 110, 1-75, 2011.

Borken, W. and Matzner, E.: Reappraisal of drying and wetting effects on $\mathrm{C}$ and $\mathrm{N}$ mineralization and fluxes in soils, Glob. Change Biol., 15, 808-824, 2008.

Brzostek, E. R., Dragoni, D., Brown, Z. A., and Phillips, R. P.: Mycorrhizal type determines the magnitude and direction of rootinduced changes in decomposition in a temperate forest, New Phytol., 206, 1274-1282, 2015.

Butman, D. E., Wilson, H. F., Barnes, R. T., Xenopoulos, M. A., and Raymond, P. A.: Increased mobilization of aged carbon to rivers by human disturbance, Nature Geosci., 8, 112-116, 2014.

Buurman, P., Bartoli, F., Basile, A., Füleky, G., Garcia Rodeja, E., Hernandez Moreno, J., and Madeira, M.: The physico-chemical database, in: Soils of Volcanic Regions in Europe, edited by: Arnalds, Ó., Óskarsson, H., Bartoli, F., Buurman, P., Stoops, G., and García-Rodeja, E., Springer, Berlin, 271-287, 2007.

Carlton, R., Berry, P., and Smith, P.: Impact of crop yield reduction on GHG emissions from compensatory cultivation of pasture and forested land, Int. J. Agric. Sust., 8, 164-175, 2010.

Carlton, R., West, J., Smith, P., and Fitt, B.: A comparison of GHG emissions from UK field crop production under selected arable systems with reference to disease control, Eur. J. Plant Path., 133, 333-351, 2012.

Carpenter, S. R., Caraco, N. F., Correll, D. L., Howarth, R. W., Sharpley, A. N., and Smith, V. H.: Nonpoint pollution of surface waters with phosphorus and nitrogen, Ecol. Appl., 8, 559-568, 1998.

Certini, G.: Effects of fire on properties of forest soils: a review, Oecologia, 143, 1-10, 2005.

Chabbi, A., Kögel-Knabner, I., and Rumpel, C.: Stabilised carbon in subsoil horizons is located in spatially distinct parts of the soil profile, Soil Biol. Biochem., 41, 256-271, 2009.

Ciais, P. and Sabine, C.: Carbon and other biogeochemical cycles, in: Climate Change 2013: The Physical Science Basis. Contribution of Working Group I to the Fifth Assessment Report of the Intergovernmental Panel on Climate Change, edited by: Edenhofer, O., Pichs-Madruga, R., and Sokonaet, Y., Cambridge University Press, Cambridge, United Kingdom and New York, NY, USA, 2013.

Clark, J. M., Heinemeyer, A., Martin, P., and Bottrell, S. H.: Processes controlling DOC in pore water during simulated drought cycles in six different UK peats, Biogeochem., 109, 253-270, 2012.

Conant, R. T., Ryan, M. G., Ågren, G. I., Birge, H. E., Davidson, E. A., Eliasson, P. E., Evans, S.E., Frey, S. D., Giardina, C. P., Hopkins, F. M., Hyvönen, R., Kirschbaum, M. U. F., Lavallee, J. M., Leifeld, J., Parton, W. J., Steinweg, J. M., Wallenstein, M. D., Wetterstedt, J. A. M., and Bradford, M. A.: Temperature and soil organic matter decomposition rates - synthesis of current knowledge and a way forward, Glob. Change Biol., 17, 33923404, 2011.

Cotrufo, M. F., Wallenstein, M. D., Boot, C., Denef, K., and Paul, E.: The microbial efficiency-matrix stabilisation (MEMS) framework integrates plant litter decomposition with soil organic matter stabilization: do labile plant inputs form stable organic matter?, Glob. Change Biol., 19, 988-995, 2013.

Das, B., Chakraborty, D., Singh, V. K., Aggarwal, P., Singh, R., Dwivedi, B. S., and Mishra, R. P.: Effect of integrated nutri- 
ent management practice on soil aggregate properties, its stability and aggregate-associated carbon content in an intensive ricewheat system, Soil Till. Res., 136, 9-18, 2014.

Decaëns, T., Jiménez, J. J., Gioia, C., Measey, G. J., and Lavelle, P.: The value of soil animals for conservation biology, Eur. J. Soil. Biol., 60, 807-819, 2006.

Dominati, E., Patterson, M., and Mackay, A.: A framework for classifying and quantifying the natural capital and ecosystem services of soils, Ecol. Econ., 69, 1858-1868, 2010.

Don, A., Schumacher, J., and Freibauer, A.: Impact of tropical landuse change on soil organic carbon stocks - a meta-analysis, Glob. Change Biol., 17, 1658-1670, 2011.

Dümig, A., Häusler, W., Steffens, M., and Kögel-Knabner, I.: Clay fractions from a soil chronosequence after glacier retreat reveal the initial evolution of organo-mineral associations, Geochim. Cosmochim. Acta, 85, 1-18, 2012.

Dungait, J. A. J., Hopkins, D. W., Gregory, A. S., and Whitmore, A. P.: Soil organic matter turnover is governed by accessibility not recalcitrance, Glob. Change Biol., 18, 1781-1796, 2012.

Dymond, J.: Ecosystem services in New Zealand, Manaaki Whenua Press, Lincoln, New Zealand, 540 p., 2014.

Erisman, J. W., Sutton, M. A., Galloway, J., Klimont, Z., and Winiwarter, W.: How a century of ammonia synthesis changed the world, Nature Geosci. 1, 636-639, 2008.

European Commission, Organisation for Economic Co-operation and Development, United Nations and World Bank: System of Environmental-Economic Accounting 2012. ExperimentalEconomic Accounting, White cover publication, 2013.

European Commission, Eurostat, United Nations, Food and Agriculture Organization of the United Nations, International Monetary Fund, Organisation for Economic Co-operation and Development and World Bank: System of Environmental-Economic Accounting 2012 Central Framework, New York; Luxembourg: UNO; Publications Office, available at: http://bookshop.europa. eu/uri?target=EUB:NOTICE:KS0114120:EN:HTML (last access: 27 May 2015), 2014.

FAOSTAT: http://faostat3.fao.org/home/E, last access: 28 March 2015.

Fierer, N. and Jackson, R. B.: The diversity and biogeography of soil bacterial communities, P. Natl. Acad. Sci. USA, 103, 626631, 2006.

Fierer, N., Ladau, J., Clemente, J. C., Leff, J., Owens, S. M., Pollard, K. S., Knight, R., Gilbert, J. A., and McCulley, R. L.: Reconstructing the microbial diversity and function of pre-agricultural tallgrass prairie soils in the United States, Science, 342, 621-624, 2013.

Finzi, A. C., Abramoff, R. Z., Spiller, K. S., Brzostek, E. R., Darby, B. A., Kramer, M. A., and Phillips, R. P.: Rhizosphere processes are quantitatively important components of terrestrial carbon and nutrient cycles, Glob. Change Biol., 21, 2082-2094, 2015.

Fisher, B. R., Turner, K., and Morling, P.: Defining and classifying ecosystem services for decision making, Ecol. Econ., 68, 643653, 2009

Fontaine, S., Mariotti, A., and Abbadie, L.: The priming effect of organic matter: a question of microbial competition, Soil Biol. Biochem., 35, 837-843, 2003.

Freeman, C., Ostle, N., and Kang, H.: An enzymic "latch" on a global carbon store, Nature, 409, 149, 2001.
Furusaka, C.: Global environment and microorganisms, B. Jpn. Soc. Microb. Ecol., 8, 127-131, 1993.

Fuss, S., Canadell, J. G., Peters, G. P., Tavoni, M., Andrew, R. M., Ciais, P., Jackson, R. B., Jones, C. D., Kraxner, F., Nakicenovic, N., Le Quéré, C., Raupach, M., Sharifi, A., Smith, P., and Yamagata, Y.: Betting on negative emissions, Nature Clim. Change, 4, 850-853, 2014.

Galloway, J. N., Townsend, A. R., Erisman, J. W., Bekunda, M., Cai, Z., Freney, J. R., Martinelli, L. A., Seitzinger, S. P., and Sutton, M. A.: Transformation of the nitrogen cycle: recent trends, questions, and potential solutions, Science, 320, 889-892, 2008.

Gans, J., Wolinsky, M., and Dunbar, J.: Computational improvements reveal great bacterial diversity and high metal toxicity in soil, Science, 309, 1387-1390, 2005.

Gärdenäs, A. I., Ågren, G. I., Bird, J. A., Clarholm, M., Hallin, S., Ineson, P., Kätterer, T., Knicker, H., Nilsson, S. I., Näsholm, T., Ogle, S., Paustian, K., Persson, T., and Stendahl, J.: Knowledge gaps in soil carbon and nitrogen interactions - From molecular to global scale, Soil Biol. Biochem., 43, 702-717, 2011.

Gattinger, A., Muller, A., Haenia, M., Skinner, C., Fließbach, A., Buchmann, N., Mädera, P., Stolzea, M., Smith, P., El-Hage Scialabbad, N., and Niggli, U.: Enhanced top soil carbon stocks under organic farming - a global meta-analysis, P. Natl. Acad. Sci. USA, 109, 18226-18231, 2012.

Ghassemi, F., Jakeman, A. J., and Nix, H.: Salinisation of land and water resources: human causes, extent, management and case studies, Centre for Resource and Environmental Studies, Canberra, Australia, 544 p., 1995.

Godbold, D. L., Hoosbeek, M. R., Lukac, M. Cotrufo, M. F., Janssens, I. A., Ceulemans, R., Polle, A., Velthorst, E. J., Scarascia-Mugnozza, G., De Angelis, P., Miglietta, F., and Peressotti, A.: Mycorrhizal hyphal turnover as a dominant process for carbon input into soil organic matter, Plant Soil 281, 15-24, 2006.

Gorham, E.: Northern peatlands: Role in the carbon cycle and probable responses to climatic warming, Ecol. Appl., 1, 182-195, 1991.

Griffiths, R. I., Thomson, B. C., James, P., Bell, T., Bailey, M., and Whiteley, A. S.: The bacterial biogeography of British soils, Environ. Microbiol. 13, 1642-1654, 2011.

Guo, L. B. and Gifford, R. M. Soil carbon stocks and land use change: a meta-analysis, Glob. Change Biol., 8, 345-360, 2002.

Güsewell, S.: N : P ratios in terrestrial plants: variation and functional significance, New Phytol., 164, 243-266, 2004.

Guswa, A. J., Brauman, K. A., Brown, C., Hamel, P., Keeler, B. L., and Sayre, S. S.: Ecosystem services: Challenges and opportunities for hydrologic modelling to support decision making, Wat. Resour. Res., 50, 4535-4544, 2014.

Haines-Young, R. and Potschin, M. CICES Version 4: Response to Consultation, Centre for Environmental Management, University of Nottingham, Nottingham, UK, 2012.

House, G. J. and Parmelee, R. W.: Comparison or soil arthropods and earthworms from conventional and no-tillage agroecosystems, Soil Till. Res., 5, 351-360, 1985.

Huang, M., Yang, L., Qin, H. D., Jiang, L. G., and Zou, Y. B.: Quantifying the effect of biochar amendment on soil quality and crop productivity in Chinese rice paddies, Field Crops Res., 154, 172177, 2013. 
IPCC: Supplement to the 2006 Guidelines for National Greenhouse Gas Inventories: Wetlands, Cambridge University Press, Cambridge, UK, 2013.

Janzen, H. H.: The soil carbon dilemma: Shall we hoard it or use it?, Soil Biol. Biochem., 38, 419-424, 2006.

Jenkinson, D. S.: Studies on the decomposition of ${ }^{14}$ C-labelled organic matter in soil, Soil Sci., 111, 64-70, 1971.

Kalbitz, K. and Kaiser, K.: Cycling downwards - dissolved organic matter in soils, Soil Biol. Biochem., 52, 29-32, 2012.

Kell, D.: Large-scale sequestration of atmospheric carbon via plant roots in natural and agricultural ecosystems: why and how, Phil. Trans. R. Soc. B, 367, 1589-1597, 2012.

Kibblewhite, M., Ritz, K., and Swift, M.: Soil health in agricultural systems, Phil. Trans. R. Soc. B, 363, 685-701, 2008.

Kirkham, M. B.: Principles of soil and plant water relations, Academic Press, San Diego, CA, 2014.

Knicker, H.: How does fire affect the nature and stability of soil organic nitrogen and carbon? A review, Biogeochem., 85, 91118, 2007.

Köhler, P., Hartmann, J., and Wolf-Gladrow, D. A.: Geoengineering potential of artificially enhanced silicate weathering of olivine, $P$. Natl. Acad. Sci. USA, 107, 20228-20233, 2010.

Kuzyakov, Y., Freidel, J. K., and Stahr, K.: Review of mechanisms and quantification of priming effects, Soil Biol. Biochem., 32, 1485-1498, 2000.

Lal, R.: Residue management, conservation tillage and soil restoration for mitigating greenhouse effect by $\mathrm{CO}_{2}$-enrichment, Soil Till. Res., 43, 81-107, 1997.

Lal, R.: Soil carbon sequestration impacts on global climate change and food security, Science, 304, 1623-1627, 2004.

Lal, R.: Sequestration of atmospheric $\mathrm{CO}_{2}$ in global carbon pools, Energy Env. Sci., 1, 86-100, 2008.

Liu, X. Y., Ye, Y. X., and Liu, Y. M.: Sustainable biochar effects for low carbon crop production: A three year field experiment in Central China, Agric. Syst., 129, 22-29, 2014.

Liu, Z. H., Jiang, L. H., Zhang, W. J., Zheng, F. L., Wang, M., and Lin, H. T.: Evolution of fertilization rate and variation of soil nutrient contents in greenhouse vegetable cultivation in Shandong, Pedologica Sinica, 45, 296-303, 2008.

Lorenz, K., Lal, R., Preston, C. M., and Nierop, K. G. I. M: Strengthening the soil organic carbon pool by increasing contributions from recalcitrant aliphatic bio(macro)molecules, Geoderma, 142, 1-10, 2007.

Lugato, E., Berti, A., and Giardini, L.: Soil organic carbon (SOC) dynamics with and without residue incorporation in relation to different nitrogen fertilisation rates, Geoderma, 135, 315-321, 2006.

MacDonald, G. K., Bennett, E. M., Potter, P. A., and Ramankutty, N.: Agronomic phosphorus imbalances across the world's croplands, P. Natl. Acad. Sci. USA, 108, 3086-3091, 2011.

Marshall, M. R., Francis, O. J., Frogbrook, Z. L., Jackson, B. M., McIntyre, N., Reynolds, B., Solloway, I., Wheater, H. S., and Chell, J.: The impact of upland land management on flooding: results from an improved pasture hillslope, Hydrol. Processes, 23, 464-475, 2009.

Matson, P. A., Parton, W. J., Power, A. G., and Swift, M. J.: Agricultural intensification and ecosystem properties, Science, 277, 504-509, 1997.
Mbow, C., Smith, P., Skole, D., Duguma, L., and Bustamante, M.: Achieving mitigation and adaptation to climate change through sustainable agroforestry practices in Africa, Curr. Op. Env. Sust., 6, 8-14, 2014.

McDowell, R. W. and Srinivasan, M. S.: Identifying critical source areas for water quality: 2 . Validating the approach for phosphorus and sediment losses in grazed headwater catchments, J. Hydrol., 379, 68-80, 2009.

McDowell, R. W., Houlbrooke, D. J., Muirhead, R. W., Müller, K., Shepherd, M., and Cuttle, S. P.: Grazed Pastures and Surface Water Quality, Nova Science Publishers, New York, NY, 2008.

McDowell, R. W., van der Weerden, T. J., and Campbell, J.: Nutrient losses associated with irrigation, intensification and management of land use: a study of large scale irrigation in North Otago, New Zealand, Agric. Water Manage., 98, 877-885, 2011.

McDowell, R. W., Cox, N., Daughney, C. J., Wheeler, D., and Moreau, M.: A national assessment of the potential linkage between soil, and surface and groundwater concentrations of phosphorus, J. Am. Water Res. Assoc., 51, 992-1002, 2015.

McSherry, M. E. and Ritchie, M. E.: Effects of grazing on grassland soil carbon: a global review, Glob. Change Biol., 19, 1347-1357, 2013.

Mikutta, R. and Kaiser, K.: Organic matter bound to mineral surfaces: Resistance to chemical and biological oxidation, Soil Biol. Biochem., 43, 1738-1741, 2011.

Millennium Ecosystem Assessment: Ecosystems and Human WellBeing: Synthesis, World Resource Institute, Island Press, Washington, D.C., USA, 2005.

Miltner, A., Bombach, P., Schmidt-Brücken, B., and Kästner, M.: SOM genesis: microbial biomass as a significant source, Biogeochem., 111, 41-55, 2012.

Moore, S., Evans, C. D., Page, S. E., Garnett, M. H., Jones, T. G., Freeman, C., Hooijer, A., Wiltshire, A. J., Limin, S. H., and Gauci, V.: Deep instability of deforested tropical peatlands revealed by fluvial organic carbon fluxes, Nature, 493, 660-663, 2013.

Naisse, C., Girardin, C., Lefèvre, R., Pozzi, A., Maas, R. Stark, A., and Rumpel, C.: Effect of physical weathering on the carbon sequestration potential of biochars and hydrochars in soil, Glob. Change Biol. Bioenergy, 7, 488-496, 2015.

Ngo, P. T., Rumpel, C., Doan T. T., Henry-des-Tureaux, T., Dang, D.-K., and Jouquet, P.: Use of organic substrates for increasing soil organic matter quality and carbon sequestration of tropical degraded soil (a 3 years mesocosms experiment), Carbon Manage, 5, 155-168, 2014.

Nordt, L. C., Wilding, L. P., and Drees, L. R.: Pedogenic carbonate transformations in leaching soil systems: Implications for the global $\mathrm{C}$ cycle, in: Global Climate Change and Pedogenic Carbonates, edited by: Lal, R., Kimble, J. M., Eswaran, H., and Stewart, B. A., Lewis Publishers, Boca Raton, FL, USA, 43-64, 2000.

Ogle, S. M., Breidt, F. J., and Paustian, K.: Agricultural management impacts on soil organic carbon storage under moist and dry climatic conditions of temperate and tropical regions, Biogeochem., 72, 87-121, 2005.

Olid, C., Nilsson, M. B., Eriksson, T., and Klaminder, J.: The effects of temperature and nitrogen and sulfur additions on carbon accumulation in a nutrient-poor boreal mire: Decadal effects assessed 
using $210 \mathrm{~Pb}$ peat chronologies, J. Geophys. Res.-Biogeosci., 119, 392-403, 2014.

Pan, G., Zhou, P., Li, Z. P., Smith, P., Li, L. Q., Qiu, D. S., Zhang, X. H., Xu, X. B., Shen, S. Y., and Chen, X. M.: Combined inorganic/organic fertilization enhances $\mathrm{N}$ efficiency and increases rice productivity through organic carbon accumulation in a rice paddy from the Tai Lake region, China, Agr. Ecosys. Env., 131, 274-280, 2009.

Pan, G., Huang, Z. Q., Wang, J. K., Li, H., Chabbi, A., Paustian, K., and Smith, P.: Soil organic matter dynamics: beyond carbon; A report of the 4th International Symposium on Soil Organic Matter Dynamics, Carbon Manage., 4, 485-489, 2013.

Pan, G., Li, L. Q., Zheng, J. F., Cheng, K., Zhang, X. H., Zheng, J. W., and Li, Z. C.: Managing soil organic carbon for multiple benefits case studies - positive exemplars. Benefits of SOM in agro-ecosystems: A case of China, Chapter 27, in: Benefits of Soil Carbon, edited by: Banwart, S., SCOPE Volume 71, CAB International, 383-401, 2014.

Parr, J. F., Gardner, W. R., and Elliot, L. F.: Water potential relations in soil microbiology: proceedings of a symposium, SSSA Special Publication number 9, Soil Science Society of America, Madison, WI, 151 pp., 1981.

Paul, E. A.: Soil microbiology, ecology and biochemistry, Academic Press, Burlington, MA, USA and Oxford, UK, 2014.

Paustian, K., Andrén, O., Janzen, H. H., Lal, R., Smith, P., Tian, G., and Woomer, P. L.: Agricultural soils as a sink to mitigate $\mathrm{CO}_{2}$ emissions, Soil Use Manage., 13, 230-244, 1997.

Peltoniemi, M., Thürig, E., Ogle, S., Palosuo, T., Shrumpf, M., Wützler, T., Butterbach-Bahl, K., Chertov, O., Komarov, A., Mikhailov, A., Gärdenäs, A., Perry, C., Liski, J., Smith, P., and Mäkipää, R.: Models in country scale carbon accounting of forest soils, Silva Fennica, 41, 575-602, 2007.

Powlson, D. S., Stirling, C. M., Jat, M. L., Gerard, B. G., Palm, C. A., Sanchez, P. A., and Cassman, K. G.: Limited potential of no-till agriculture for climate change mitigation, Nature Clim. Change, 4, 678-683, 2014.

Quinton, J. N., Govers, G., Van Oost, K., and Bardgett, R. D.: The impact of agricultural soil erosion on biogeochemical cycling, Nature Geosci. 3, 311-314, 2010.

Radajewski, S., Ineson, P., Parekh, N. R., and Murrell, J. C.: Stableisotope probing as a tool in microbial ecology, Nature, 403, 646649, 2000

Rasse, D. P., Rumpel, C., and Dignac, M.-F.: Is soil carbon mostly root carbon? Mechanisms for a specific stabilisation, Plant Soil, 269, 341-356, 2005.

Reay, D., Smith, P., and van Amstel, A. (Eds.): Methane and Climate Change, Earthscan, London, 272 pp., 2010.

Reichstein, M., Bahn, M., Ciais, P., Frank, D., Mahecha, M. D., Seneviratne, S. I., Zscheischler, J., Beer, C., Buchmann, N., Frank, D. C., Papale, D., Rammig, A., Smith, P., Thonicke, K., van der Velde, M., Vicca, S., Walz, A., and Wattenbach, M.: Climate extremes and the carbon cycle, Nature, 500, 287-295, 2013.

Rillig, M. C.: Arbuscolar mycorrhizae, glomalin and soil aggregation, Can. J. Soil Sci., 84, 355-363, 2004.

Robinson, D. A., Lebron, I., and Vereecken, H.: On the definition of the natural capital of soils: A framework for description, evaluation, and monitoring, Soil Sci. Soc. Am. J., 73, 1904-1911, 2009.
Robinson, D. A., Hockley, N., Cooper, D. M., Emmett, B. A., Keith A. M., Lebron, I., Reynolds, B., Tipping, E., Tye, A. M., Watts, C. W., Whalley, W. R., Black, H. I. J., Warren, G. P., and Robinson, J. S.: Natural capital and ecosystem services, developing an appropriate soils framework as a basis for valuation, Soil Biol. Biochem., 57, 1023-1033, 2013.

Robinson, D. A., Fraser, I, Dominati, E. J., Davíðsdóttir, B., Jónsson, J. O. G., Jones, L. Jones, S. B., Tuller, M., Lebron, I., Bristow, K. L., Souza, D. M., Banwart, S., and Clothier, B. E.: On the value of soil resources in the context of natural capital and ecosystem service delivery, Soil Sci. Soc. Am. J., 78, 685-700, 2014.

Rumpel, C. and Kögel-Knabner, I.: Deep soil organic matter - a key but poorly understood component of terrestrial C cycle, Plant Soil, 338, 143-158, 2011.

Sanaullah, M., Blagodatskaya, E., Chabbi, A., Rumpel, C., and Kuzyakov, Y.: Drought effects on microbial biomass and enzyme activities in the rhizosphere of grasses depend on plant community composition, Appl. Soil Ecol., 48, 38-44, 2011.

Sanaullah, M., Chabbi, A., Rumpel, C., and Kuzyakov, Y.: Carbon allocation in grassland communities under drought stress followed by ${ }^{14} \mathrm{C}$ pulse labelling, Soil Biol. Biochem., 55, 132-139, 2012.

Sanaullah, M., Chabbi, A., Girardin, C., Durand, J. L., Poirier, M., and Rumpel, C.: Effects of drought and elevated temperature on biochemical composition of forage plants and their impact on carbon storage in grassland soil, Plant Soil, 374, 767-778, 2014.

Sato, T., Qadir, M., Yamamoto, S., Endo, T., and Zahoor, A.: Global, regional, and country level need for data on wastewater generation, treatment, and use, Agric. Water Manage., 130, 1-13, 2013.

Schlesinger, W. M. and Bernhardt, E. S.: Biogeochemstry. An analysis of global change, 3rd Edition, Academic Press, NY, USA, 2013.

Schmidt, M. W. I. and Noack, A. G.: Black carbon in soils and sediments: Analysis, distribution, implications, and current challenges, Glob. Biogeochem. Cycles, 14, 777-793, 2000.

Scholes, M. J. and Scholes, R. J.: Dust unto dust, Science, 342, 565 566, 2013.

Setia, R., Marschner, P., Baldock, J., Chittleborough, D., Smith, P., and Smith, J. U.: Salinity effects on carbon mineralization in soils of varying texture, Soil Biol. Biochem., 43, 1908-1916, 2011.

Singh, N., Abiven, S., Torn, M. S., and Schmidt, M. W. I.: Fire-derived organic carbon in soil turns over on a centennial scale, Biogeosciences, 9, 2847-2857, doi:10.5194/bg-9-28472012, 2012.

Smil, V.: Phosphorus in the environment: natural flows and human interferences, Annual Rev. Energy Environ., 25, 53-88, 2000.

Smith, J. U., Gottschalk, P., Bellarby, J., Chapman, S., Lilly, A., Towers, W., Bell, J., Coleman, K., Nayak, D. R., Richards, M. I., Hillier, J., Flynn, H. C., Wattenbach, M., Aitkenhead, M., Yeluripurti, J. B., Farmer, J., Milne, R., Thomson, A., Evans, C., Whitmore, A. P., Falloon, P., and Smith, P.: Estimating changes in national soil carbon stocks using ECOSSE - a new model that includes upland organic soils. Part I. Model description and uncertainty in national scale simulations of Scotland, Climate Res., 45, 179-192, 2010.

Smith, P.: Soils as carbon sinks - the global context, Soil Use Manage., 20, 212-218, 2004. 
Smith, P.: Soils and climate change, Curr. Op. Env. Sust., 4, 539544, 2012.

Smith, P., Ashmore, M., Black, H., Burgess, P. J., Evans, C., Quine, T., Thomson, A. M., Hicks, K., and Orr, H.: The role of ecosystems and their management in regulating climate, and soil, water and air quality, J. Appl. Ecol., 50, 812-829, 2013.

Smith, P., Bustamante, M., Ahammad, H., Clark, H., Dong, H., Elsiddig, E. A., Haberl, H., Harper, R., House, J., Jafari, M., Masera, O., Mbow, C., Ravindranath, N. H., Rice, C. W., Robledo Abad, C., Romanovskaya, A., Sperling, F., and Tubiello, F.: Agriculture, Forestry and Other Land Use (AFOLU), in: Climate Change 2014: Mitigation of Climate Change, Contribution of Working Group III to the Fifth Assessment Report of the Intergovernmental Panel on Climate Change, edited by: Edenhofer, O., Pichs-Madruga, R., Sokona, Y., Farahani, E., Kadner, S., and Seyboth, K., Cambridge University Press, Cambridge, United Kingdom and New York, NY, USA, 2014.

Smith, P., House, J. I., Bustamante, M., Sobocká, J., Harper, R., Pan, G., West, P. C., Clark, J. M., Adhya, T., Rumpel, C., Paustian, K., Kuikman, P., Cotrufo, M. F., Elliott, J. A., McDowell, R., Griffiths, R. I., Asakawa, S., Bondeau, A., Jain, A. K, Meersmans, J., and Pugh, T. A. M.: Global change pressures on soils from land use and management, Glob. Change Biol., in press, doi:10.1111/gcb.13068, 2015.

Snyder, C. S., Davidson, E. A., Smith, P., and Venterea, R. T.: Agriculture: sustainable crop and animal production to help mitigate nitrous oxide emissions, Curr. Op. Environ. Sust., 9-10, 46-54, 2014.

Sollins, P., Homann, P., and Caldwell, B. A.: Stabilization and destabilization of soil organic matter: mechanisms and controls, Geoderma, 74, 65-105, 1996.

Song, X. Y., Li, L. Q., Zheng, J. F., Pan, G., Zhang, X. H., Zheng, J. W., Hussain, Q., Han, X. J., and Yu, X. Y.: Sequestration of maize crop straw $\mathrm{C}$ in different soils: role of oxyhydrates in chemical binding and stabilization as recalcitrance, Chemosphere, 87, 649-654, 2012.

State Bureau of Statistics-China: 50 Years Rural Statistics of New China; China Statistics Press, Beijing, China, 2005.

Steinfeld, H., Gerber, P., Wassenaar, C. V., Rosales, M., and de Haan, C.: Livestock's long shadow, Food and Agriculture Organization of the United Nations, Rome, Italy, available at: http://www.fao.org/docrep/010/a0701e/a0701e00.htm (last access: August 2014), 2006.

Stewart, C. E., Zheng, J. Y., Botte, J., and Cotrufo, M. F.: Cogenerated fast pyrolysis biochar mitigates greenhouse gas emissions and increases carbon sequestration in temperate soils, Glob. Change Biol. Bioenergy, 5, 153-164, 2013.

Sutton, M. A., Nemitz, E., Erisman, J. W., Beier, C., Butterbach Bahl, K., Cellier, P., de Vries, W., Cotrufo, F., Skiba, U., Di Marco, C., Jones, S., Laville, P., Soussana, J. F., Loubet, B., Twigg, M., Famulari, D., Whitehead, J., Gallagher, M. W., Neftel, A., Flechard, C. R., Herrmann, B., Calanca, P. L., Schjoerring, J. K., Daemmgen, U., Horvath, L., Tang, Y. S., Emmett, B. A., Tietema, A., Peñuelas, J., Kesik, M., Brueggemann, N., Pilegaard, K., Vesala, T., Campbell, C. L., Olesen, J. E., Dragosits, U., Theobald, M. R., Levy, P., Mobbs, D. C., Milne, R., Viovy, N., Vuichard, N., Smith, J. U., Smith, P., Bergamaschi, P., Fowler, D., and Reis, S.: Challenges in quantifying biosphere- atmosphere exchange of nitrogen species, Environ. Poll., 150, 125-139, 2007.

Tarnocai, C., Canadell, J. G., Schuur, E. A. G., Kuhry, P., Mazhitova, G., and Zimov, S.: Soil organic carbon pools in the northern circumpolar permafrost region, Glob. Biogeochem. Cycles, 23, GB2023, doi:10.1029/2008GB003327, 2009.

Thévenot, M., Dignac, M.-F., and Rumpel, C.: Fate of lignins in soils: a review, Soil Biol. Biochem., 42, 1200-1211, 2010.

Tilman, D., Cassman, K. G., Matson, P. A., Naylor, R., and Polasky, S.: Agricultural sustainability and intensive production practices, Nature, 418, 671-677, 2002.

Todd-Brown, K. E. O., Randerson, J. T., Post, W. M., Hoffman, F. M., Tarnocai, C., Schuur, E. A. G., and Allison, S. D.: Causes of variation in soil carbon simulations from CMIP5 Earth system models and comparison with observations, Biogeosciences, 10, 1717-1736, doi:10.5194/bg-10-1717-2013, 2013.

Trumbore, S.: Radiocarbon and soil carbon dynamics, Ann. Rev. Earth Planet. Sci., 37, 47-66, 2009.

Turunen, J., Roulet, N. T., Moore, T. R., and Richard, P. J. H.: Nitrogen deposition and increased carbon accumulation in ombrotrophic peatlands in eastern Canada, Glob. Biogeochem. Cycles, 18, GB3002, doi:10.1029/2003GB002154, 2004.

UKNEA: The UK National Ecosystem Assessment. Synthesis of the Key Findings, UNEP-WCMC, Cambridge, 2011.

Van Groenigen, J. W., Velthof, G. L., Oenema, O., Van Groenigen, K. J., and Van Kessel, C.: Towards an agronomic assessment of $\mathrm{N}_{2} \mathrm{O}$ emissions: a case study for arable crops, Eur. J. Soil Sci., 61, 903-913, 2010.

Van Oost, K., Quine, T. A., Govers, G., De Gryze, S., Six, J., Harden, J. W., Ritchie, J. C., McCarty, G. W., Heckrath, G., Kosmas, C., Giraldez, J. V., da Silva, J. R. M., and Merckx, R.: The impact of agricultural soil erosion on the global carbon cycle, Science, 318, 626-629, 2007.

Venterea, R. T., Maharjan, B., and Dolan M. S.: Fertilizer source and tillage effects on yield-scaled nitrous oxide emissions in a corn cropping system, J. Environ. Qual., 40, 1521-1531, 2011.

Vitousek, P. M. and Matson, P. A.: Biological diversity and terrestrial ecosystem biogeochemistry, in: The biogeochemistry of global change: radiative trace gases, edited by: Oremland, R. S., Chapman and Hall, New York, 193-208, 1993.

Vogel, C., Mueller, C. W., Hoschen, C., Buegger, F., Heister, K., Schulz, S., Schloter, M., and Kogel-Knabner, I.: Submicron structures provide preferential spots for carbon and nitrogen sequestration in soils, Nature Comm., 5, 2947, doi:10.1038/ncomms3, 2014.

von Lützow, M., Kögel-Knabner, I., Ekschmitt, K., Matzner, E., Guggenberger, G., Marschner, B., and Flessa, H.: Stabilization of organic matter in temperate soils: mechanisms and their relevance under different soil conditions - a review. Euro. J. Soil Sci., 57, 426-445, 2006.

von Lützow, M., Kögel-Knabner, I., Ludwig, B., Matzner, E., Flessa, H., Ekschmitt, K. Guggenberger, G., Marschner, B., and Kalbitz, K.: Stabilization mechanisms of organic matter in four temperate soils: Development and application of a conceptual model, J. Plant Nut. Soil Sci., 171, 111-124, 2008.

Walthall, C. L., Hatfield, J., Backlund, P., Lengnick, L., Marshall, E., Walsh, M., Adkins, S., Aillery, M., Ainsworth, E. A., Ammann, C., Anderson, C. J., Bartomeus, I., Baumgard, L. H., Booker, F., Bradley, B., Blumenthal, D. M., Bunce, J., Burkey, 
K., Dabney, S. M., Delgado, J. A., Dukes, J., Funk, A., Garrett, K., Glenn, M., Grantz, D. A., Goodrich, D., Hu, S., Izaurralde, R. C., Jones, R. A. C., Kim, S.-H., Leaky, A. D. B., Lewers, K., Mader, T. L., McClung, A., Morgan, J., Muth, D. J., Nearing, M., Oosterhuis, D. M., Ort, D., Parmesan, C., Pettigrew, W. T., Polley, W., Rader, R., Rice, C., Rivington, M., Rosskopf, E., Salas, W. A., Sollenberger, L. E., Srygley, R., Stöckle, C., Takle, E. S., Timlin, D., White, J. W., Winfree, R., Wright-Morton, L., and Ziska, L. H.: Climate change and agriculture in the united states: effects and adaptation, USDA Technical Bulletin 1935, Washington, D.C., 186 p., 2012.

Wei, X., Shao, M., Gale, W., and Li, L.: Global pattern of soil carbon losses due to the conversion of forests to agricultural land, Scientific Reports, 4, 4062, doi:10.1038/srep04062, 2014.

West, P. C., Gerber, J. S., Engstrom, P. M., Mueller, N. D., Brauman, K. A., Carlson, K. M., Cassidy, E. S., Johnston, M., MacDonald, G. K., Ray, D., and Siebert, S.: Leverage points for improving global food security and the environment, Science, 345 , 325-328, 2014.

West, T. O. and Post, W. M.: Soil organic carbon sequestration rates by tillage and crop rotation: A global data analysis, Soil Sci. Soc. Am. J., 66, 1930-1946, 2002.

Wiedner, K., Rumpel, C., Pozzi, A., Maas, R., Steiner, C., and Glaser, B.: Chemical evaluation of chars produced by thermochemical conversion (gasification, pyrolysis and hydrothermal carbonization) of agro-industrial biomass on a commercial scale, Biomass Bioenergy, 59, 264-278, 2013.
Whitmore, A. P., Kirk, G. J. D., and Rawlins, B. G.: Technologies for increasing carbon storage in soil to mitigate climate change, Soil Use Manage., 30, 10-22, 2014.

Wilkinson, M. T., Richards, P. J., and Humphreys, G. S.: Breaking ground: Pedological, geological and ecological implications of soil biotrubation, Earth Sci. Rev., 97, 257-272, 2009.

Yu, Z. C.: Northern peatland carbon stocks and dynamics: a review, Biogeosci. 9, 4071-4085, 2012.

Zhang, A. F., Cui, L. Q., Pan, G., Li, L, Q., Husaain, Q., Zhang, X. H., Zheng, J. W., and Crowley, D.: Effect of biochar amendment on yield and methane and nitrous oxide emissions from a rice paddy from Tai Lake plain, China, Agric. Ecosys. Environ., 139, 469-475, 2010.

Zheng, J. F., Li, L. Q., Pan, G., Zhang, X. H., Smith, P., and Hussain, Q.: Potential aerobic $\mathrm{C}$ mineralization of a red earth paddy soil and its temperature dependence under long-term fertilizer treatments, Soil Use Manage., 28, 185-193, 2012.

Zhou, P., Song, G. H., Pan, G., Li, L. Q., and Zhang, X. H.: Role of chemical protection by binding to oxyhydrates in SOC sequestration in three typical paddy soils under long-term agro-ecosystem experiments from South China, Geoderma, 153, 52-60, 2009.

Zimmermann, M., Leifeld, J., Schmidt, M. W. I., Smith, P., and Fuhrer, J.: Measured soil organic matter fractions can be related to pools in the RothC model, Euro. J. Soil Sci., 55, 658-667, 2007.

Zvomuya, F., Janzen, H. H., Larney, F. J., and Olson, B. M.: A longterm field bioassay of soil quality indicators in a semiarid environment, Soil Sci. Soc. Am. J., 72, 683-692, 2008. 